\title{
A Contrarian Voice: Şehzāde Ķorḳud's (d. 919/1513) Writings on Kalām and the Early Articulation of Ottoman Sunnism
}

\author{
Nabil Al-Tikriti
}

What characterizes Ottoman Sunnism, and how did it come to be? The conventional view is that by roughly the middle of the sixteenth century the imperial elite came to adopt and promote a particular religious identity, which can be characterized by several overlapping, interrelated, and historically defined denominational (madhhab) affiliations, as well as a particular relationship with the political hierarchy. The favored denominations included Hanafi legal affiliation and Maturidi kalām orientation, accompanied by elite support for particular aspects of mystical thought and practice, a cooperative relationship between favored Sufi orders and the state, and advanced integration of the ulama into a state-supported madrasa system. ${ }^{1}$ The scholarly literature on the evolution of these markers of belonging, as well as their meaning and content in an Ottoman context, has blossomed in recent years; however, much still remains to be clarified concerning the characteristics of this posited "Ottoman Sunnism" and how it came to be.

The coming together of these main factors into a coherent religious outlook evolved over approximately a century, from roughly the last quarter of the fifteenth to the middle of the sixteenth century. Prior to that period, Anatolian societies displayed a plethora of religious, spiritual, and political identities, which cannot easily be characterized as either fully Ottoman or Sunni. As Rıza Yıldırım characterized it, the religious landscape of Anatolia prior to the coming together of Ottoman Sunnism can best be described as "clusters of faiths," sharing both Sunni and Shi'i elements. ${ }^{2}$ The earliest element in the institutionalization of a comprehensive Sunni imperial identity was likely Sultan Mehmed II's (d. 886/1481) construction of a fully hierarchical

1 Similarly, Necdet Tosun has argued that if one is to speak of a "Turkish Islam," it would be defined as Maturidi in belief, Hanafi in fiqh, and following Sufi paths such as the Naqshbandi and Yesevi. Tosun, Mâtürîdiyye ve tasavvuf ilişkisi 54 .

2 Yıldırım, Sunni orthodox vs. Shi'ite heterodox 304. 
madrasa system, accompanied by a unified curriculum. ${ }^{3}$ Following the establishment of the top madrasas, a synthesis between Ash'ari and Maturidi theological approaches was embedded in the curriculum, ${ }^{4}$ along with a particularly Ottoman take on the Hanafi tradition. ${ }^{5}$ Covering theology, logic, philosophy, law, language, rhetoric, and other fields outside the physical sciences, this curriculum was heavily influenced by an earlier Timurid example of royal patronage for madrasa scholarship, which has been described as a "Sunni revival" and came to play a major role in articulating an Ottoman path of practicing Sunni Islam. ${ }^{6}$ Concurrently, after the turn of the sixteenth century, facing an explicitly Shi'i Safavid challenge, which was itself evolving, this Ottoman interpretation of Sunnism hardened further in the midst of an "age of confessionalization," which paralleled a similar (and far more extensively researched and commented upon) age in European societies. ${ }^{7}$

Before stabilizing as an institutionally consistent madrasa course of study, some of the curriculum's foundational texts and pedagogical emphases remained hotly debated, with one of the realms most in dispute being that of ușül al-dìn, or "principles of religion." The discipline within ușül al-dìn to receive the most attention has always been ilm al-kalām, or just kalām, commonly translated as "theology." ${ }^{8}$ The Ottoman madrasa curriculum included a thorough study of kalamm, perhaps because learning the classics of theological disputation provided students with a solid orientation and history of Muslim identity politics through the centuries up to that point. Likewise, by studying kalām, students could strengthen their grasp of ușül al-dìn in general, logic, and rhetorical methodology, and the factors inherent in successful theological positions. As Ottoman religious politics underwent a shift at the turn of the sixteenth century due to the Safavid challenge, that training proved quite useful, as kaläm provided one of the key tools for state-supported scholars to redefine the boundaries of sanctioned belief.

3 Atçl, Scholars and sultans.

4 Yazıcıoğlu, Le kalām; Özervarl, Theology in the Ottoman lands.

5 Burak, Second formation; Peters, What does it mean.

6 Özervarlı, Theology in the Ottoman lands; Ahmed and Filipović, The sultan's syllabus. On the Timurid madrasa curriculum, see Subtelny and Khalidov, The curriculum.

7 This terminology follows that of Krstić, Illuminated by the light.

8 As Jan Thiele has pointed out, none of these terms properly map onto Western understandings of "theology," as kaläm touches upon issues considered beyond theology's purview, while some of what is considered theological discourse in Christendom falls outside of kaläm. Due to the imprecise and constantly evolving nature of these terms, and their somewhat inconsistent use in the literature, this submission uses them interchangeably. Thiele, Recent scholarship 224. 
One figure whose writings reflect this coming together of Ottoman Sunnism at a nascent stage is Şehzāde Korkud (d. 919/1513), who argued a series of positions on matters of religious belief, doctrinal certainty, favored groups, and the relationship between the state and ulama. Largely because he failed to win power in the 917-919/1511-1513 dynastic succession struggle, the prince's arguments left a limited mark, and several of his positions reflected a minority viewpoint. However, at the same time, his positions highlight several relevant intellectual influences at that time and place, point to factors contributing to the form Ottoman Sunnism came to take, and demonstrate the range of debate inherent in elite circles at the time.

\section{Lineages of Ottoman Kalām}

Kaläm had evolved through several epochs by the time Ottoman scholars entered the arena. Early Islamic doctrinal debates were contested between a number of groups, some of the more influential consisting of: Mu'tazili supporters of full human agency, divine justice, and responsibility who accepted rational argumentation; Hanbali traditionalists who prioritized revealed knowledge (naql) - particularly prophetic hadith reports-over all other forms of proofs; and Murji'i partisans, who believed individuals would face God's judgment only in the afterlife.

In the course of these debates, which sometimes turned violent, supporters of such broad sets of positions sharpened their own stance in response to their opponents' critiques, borrowed arguments from each other, and ultimately reached a sort of consensus on certain points. Over time, as doctrinal debates continued to evolve, the original group coherence broke down, to be replaced by new groupings. Scholars, rarely obliged to follow consistent belief guidelines, frequently supported positions lifted from multiple groupings. As a result, the borders between primary belief orientations were frequently blurry, as well as constantly shifting. For example, while many Sunni scholars and theologians sympathized with various Mu'tazili views, the grouping eventually became largely identified with Twelver Shi'i philosophy, while the Murji'i strand later became identified with latitudinarian Sufism. Similarly, in the early centuries traditionalists persuasively portrayed both falsafa (philosophic rationalism) and kalām as doubt inducing and dangerous activities. ${ }^{9}$

9 Spannaus, Theology in Central Asia. 
As A.I. Sabra argued, falsafa and kalām evolved in opposition to each other, with each seeing itself as the supreme science, independent of all others. Advocates for this Islamicate form of philosophic rationalism, the most notable of which included al-Kindī (d. 259/873), al-Fārābī (d. 339/950), Ibn Sīnā/Avicenna (d. 428/1038), and Ibn Rushd/Averroes (d. 595/1198), saw themselves as searching for truth for its own sake, as contemporary representatives of ancient sciences exemplified by demonstrative proofs, doctrinal neutrality, and genuinely rational methodology. ${ }^{10}$ In response to falsafa critiques of kaläm as a pseudoscience offering little more than apologetics in defense of Islamic belief, and recognizing the power of such critiques, prominent mutakallimūn came to integrate philosophic method into their doctrinal arguments, while at the same time extending the reach of kaläm discourse into fields well beyond what modern scholars might recognize as "theology."11

Several Ash'ari scholars fleshed out kaläm's response to the falsafa critique in the fifth/eleventh to eighth/fourteenth centuries. Abū Bakr al-Bāqillānī (d. 403/1013) first supported al-Ash'ari's statements by pioneering a system of intellectual premises built on an atomistic theory of the world. In response to Aristotelian critiques of al-Bāqillānī's atomistic premises set out by the falāsifa (philosophers), especially by Avicenna, Imām al-Ḥaramayn al-Juwaynī (d. 478/1085) introduced reason ('aql) to kalām discourse. ${ }^{12}$ Following al-Juwaynī's contribution, al-Ghazāil (d. 505/1111) argued against the purely rationalist positions of the faläsifa as a whole, on the grounds that their methods were inadequate to prove several of their doctrine's main points. For this reason, he argued that the faläsifa as a group failed to demonstrate their claim of philosophic rationalism's all-encompassing demonstrative consistency. As an alternative, al-Ghazālī, and those who followed him, proposed co-opting philosophic methodology and rigor to defend kaläm positions. ${ }^{13}$ Within this school of thought, Fakhr al-Dīn al-Rāzī (d. 606/1210) perfected al-Ghazālī's challenge to the philosophers by combining and applying the methodology of rationalism ('aql) to confirm statements made by revealed knowledge (naql).

Once falsafa methodology and rhetoric had been thus co-opted into kaläm discourse, most scholars followed their lead, aside from falsafa rationalists and traditionalists, who eventually grew somewhat marginalized within mainstream Islamicate intellectual circles. In addition to marginalizing unsympathetic philosophers and traditionalists, this "Avicennan turn" in response to Ibn

\footnotetext{
10 Ulrich et al., Philosophy in the Islamic world.

11 Sabra, Science and philosophy 1-15.

12 Ibid. 12-13.

13 Frank, Al-Ghazālī's use.
} 
Sinnā's critique also transformed kalām under the aegis of an all-encompassing disciplinary approach, which came to be known as hikma (wisdom). ${ }^{14}$ Over the subsequent centuries, kaläm evolved into a rigorous philosophic school of its own, which might be more accurately classified as a "religious philosophy" or a "philosophical theology."15 By the ninth/fifteenth century, an admixture of rationalist philosophical methodology and rhetoric had been progressively incorporated into the discipline, such that the postclassical (al-mutajakhkhirūn) form of kalām came to prioritize logic, design, and strength of argumentation over madhhab affiliation. ${ }^{16}$

Living in an era defined by the dual threats of the Isma'ili $d a^{\prime} w a$ and the doubt inducing faylasūf, al-Ghazālī also strove to ensure legal effect for one's doctrinal thinking. As Frank Griffel has pointed out, al-Ghazālī denied the right of repentance (istitäba) to those found guilty of secret apostasy (zindīqs) due to their demonstrated internal beliefs, regardless of their external statements of faith. He also paved the way for state representatives to adjudicate the status of one's belief based on one's external actions, primarily by blurring the legal distinction between a Muslim guilty of internal unbelief ( $k u f r$ ) and a believer actively professing apostasy (irtidād). ${ }^{17}$ Over time, legists and other scholars elaborated on actions that signified such internal belief to the satisfaction of governing authorities. One of the earlier and more celebrated victims of this position was Shihāb al-Dīn Yahyā Suhrawardī (d. 587/1191), author of the controversial tract Hayākil al-nūr (Temples of light). Due to the bātınì (Neoplatonic, gnostic, esoteric) nature of his ishrāqi (illuminationist) writings, which went on to influence generations of philosophical Sufis, his views were considered enough of a provocation by the Ayyubid authorities of his day to justify execution. ${ }^{18}$

Coinciding with an era of great intellectual, philosophical, and political experimentation in the wake of the Mongol Irruption, in the decades and centuries after Suhrawardī's execution, several philosophically inclined scholars strove to rehabilitate Suhrawardì's ishrāqi thought and reconcile it with legal

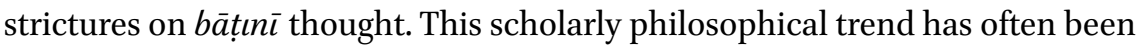
referred to by modern scholars as the "Shirazi school" - which actually appears to be two related, but somewhat distinct, intellectual clusters. Characteristic

\footnotetext{
14 Endress, Reading Avicenna 371-422.

15 Sabra, Science and philosophy 22-24.

16 Özervarl, Theology in the Ottoman lands 568.

17 Griffel, Toleration and exclusion 344-354; Al-Tikriti, Kalām in the service 131-149.

18 For an English commentary and rendering of Hayākil al-nūr, see Suhrawardī, The shape of light.
} 
of the era, the boundaries of this "Shirazi school" were not particularly well defined, nor were its scholars' doctrinal identities uniformly clear. One group was made up of predominantly Ash'ari scholars who integrated Ibn 'Arabï's (d. 638/1240) metaphysics, Suhrawardi's illuminationism, and Avicennan ideas with post-Ghāzālī kalām. Prominent scholars in this group included 'Aḍud al-Dīn al-İjī (d. 756/1355), Sa'd al-Dīn al-Taftāzānī (d. 793/139o), and al-Sayyid al-Sharīf al-Jurjānī (d. 817/1413) — each of whom came to play a major role in the Ottoman kaläm curriculum. ${ }^{19}$ A parallel Shirazi cluster was characterized by scholars who either ignored or were not remembered for engaging with kaläm but were similarly engaged with the philosophical, metaphysical, and mystical debates of the first group. Characterized as more mystically inclined, and usually discussed together with the evolution of Twelver Shi'i philosophy, such scholars included Ṣadr al-Dīn al-Qūnawī (d. 673/1274), Quṭb al-Dīn Shīrāzī (d. 710/1311), and Șadr al-Dīn Dashtaqī (d. 903/1497) ${ }^{20}$ Both groups commented on the legacies of Avicenna/Ibn Sīnā, Suhrawardī, and Ibn 'Arabì. At least two scholars were solidly entrenched in both groups, providing the tie between the two as both scholarly commonalities and chronological bookends, with Nașir al-Dīn Ṭūsì's (d. 672/1274) Tajrìd informing philosophical discussions from the inception and Jalāl al-Dīn Dawānī's (d. 908/1502) Shawākil al-hūur providing one of the last texts in common use in both Ottoman and Safavid circles. ${ }^{21}$

Dawānī, the last figure of mutual influence in these twinned Shirazi schools, mentored several students who went on to successful careers as policymakers and scholars in the Safavid, Ottoman, and Mughal Empires. Their common teacher may partially explain not only why his works were studied throughout these empires but why what has become categorized in modern scholarly literature as distinct Ottoman kalām and Twelver Shi'i philosophy schools shared several common scholars who wrote prior to the turn of the tenth/sixteenth century. ${ }^{22}$ In the wake of the Safavid revolution, with new issues to confront in a radically changed political landscape, these related schools started to go their separate ways as distinct fields. ${ }^{23}$

19 Corbin, History of Islamic philosophy 267-272; Spannaus, Theology in Central Asia 591593 .

20 Corbin, History of Islamic philosophy 205-218, 332-338; Nasr, Islamic philosophy 193-199; Nasr and Aminrazavi, Anthology of philosophy iv, 1-135; v, part I.

21 For a Twelver Shi'i commentary on Dawānīs Shawākil al-hūrr, see Rizvi, Mīr Ġiyātuddīn 104-109.

22 Özervarl, Theology in the Ottoman lands; Pourjavady and Schmidtke, Twelver Shi`̄ theology 456-469.

23 Pourjavady, Philosophy in early Safavid Iran; Rizvi, Mīr Ġiyātaddīn 104-109; Endress, Reading Avicenna 416-422. 
During the same epoch, as the Ash'ari kalām school adopted philosophical methodology and reigned supreme throughout most of the central Islamic lands, the rival Maturidi kaläm school gradually spread from Transoxania into Iran and Anatolia along with Turkic nomadic populations making their way westward. In the course of this spread westward, Maturidi scholars sharpened their arguments against Ash'ari criticism while adopting certain Ash'ari positions, so much so that ultimately the two schools grew quite intertwined. By the eighth/fourteenth century, scholars such as Tāj al-Dīn al-Subkì (d. 771/1370), Sa'd al-Dīn al-Taftāzānī (d. 793/139o), and al-Sayyid al-Sharīf al-Jurjānī (d. 817/ 1413), among others, argued that both Ash'ari and Maturidi belief systems should be recognized as legitimately falling within the broader grouping of ahl al-sunna wa-l-jamā'a (lit. "People of the Sunna and Community," i.e., Sunnis) each threatened not so much by each other as by anthropomorphist trends (mujassima), which is how Hanbali and Karrami traditionalist arguments were often labeled. ${ }^{24}$

The culmination of these intertwined intellectual trends meant that what became Ottoman kaläm was heavily influenced by positions and debates articulated by the following group of middle-period scholars: Najm al-Dīn 'Umar al-Nasafĩ (d. 536/1142), Fakhr al-Dīn al-Rāzì (d. 6o6/1210), Sayf al-Dīn al-Āmidī (d. 631/1233), Nāșir al-Dīn al-Bayḍāwī (d. 685/1286), Shams al-Dīn al-Ișfahānī (d. 749/1348), 'Aḍud al-Dīn al-İjī (d. 756/1355), Sa'd al-Dīn al-Taftāzānī (d. 793/ 1390), al-Sayyid al-Sharīf al-Jurjānī (d. 817/1413), Khayālī Ahmmad Efendi (d. 874/ 1470), and Jalāl al-Dīn Dawānī (d. 908/1502). ${ }^{25}$ With the exception of al-Nasafī, al-Taftāzānī, and Khayālī, these scholars were all Ash'ari affiliates. ${ }^{26}$ In addition, while al-Nasafî is considered a staunch Maturidi advocate, most Ottoman madrasa students read his 'Aqā'id through al-Taftāzānīs and Khayālì's commentaries on it. ${ }^{27}$ Sad al-Dīn al-Taftāzānī played something of a mediating role between al-Nasafi's positions and those of his Ash'ari colleagues, has been said to have merged Ash'ari and Maturidi positions in his Sharh al-'Aqä̉id, and cannot be reliably assigned to either school. ${ }^{28}$ Meanwhile, Khayālī Ahmad Efendi, the only Ottoman scholar Mustafa Said Yazıcıoğlu found listed in a tenth/sixteenth-century manuscript describing the Ottoman kaläm curriculum, appears to have spent much of his career adjudicating famous theological

\footnotetext{
24 Berger, Interpretations 693-701.

25 Yazıcoğlu, Le kalām 54-70.

26 Gardet, 'Ilm al-kalām.

27 Yazıcıoğlu, Le kalām 55 .

28 Würtz, Islamische Theologie im 14. Jahrhundert; Spannaus, Theology in Central Asia 591592; Berger, Interpretations 697; Eichner, Handbooks 496; Özen, Teftâzânî 299-3o8.
} 
debates between the aforementioned scholars, as he is credited with either commentaries or glosses on the treatises included in the Ottoman curriculum by al-Nasafì, al-İjī, al-Taftāzānī, al-Jurjānī, and al-Dawānī. ${ }^{29}$ In light of his own body of work, his position, and his lifespan, it seems likely that Khayālī may have played a major role in defining the first standardized Ottoman madrasa curriculum on kalām. A product of his era, Khayālī was later criticized by the Ottoman scholar 'Uthmān Kilīsī al-'Uryānī (d. 1167/1754) for insufficiently emphasizing the differences between Ash'ari and Maturidi positions-which may have simply reflected the reality that Ottoman articulations of Maturidi kaläm had grown far more detailed and distinct from its Ash'ari cousin by the twelfth/eighteenth century. ${ }^{30}$ On the whole, considering how prominent, even dominant, Ashari scholars were within the madrasa theology curriculum, just how Maturidi was Ottoman kaläm in the late ninth/fifteenth century?

A generation later, in the wake of the Safavid challenge, it appears that selfidentifying as following the Maturidi school came to carry greater importance within high Ottoman ulama circles. As if to signal this point, the powerful chief mufti (şeyhü'l-islām) Ibn Kemāl/ Kemālpaşazāde (d. 940/1534) devoted an entire treatise to clarifying doctrinal differences between the Maturidi and Ash'ari schools, ${ }^{31}$ which was one of a long line of Ottoman ulama treatises engaging with Tāj al-Dīn al-Subkì's doctrinal poem describing Ash'ari positions, al-Nūniyya. ${ }^{32}$ As the early Ottoman theologian Hiżır Beg (d. 863/1459) completed an Arabic versed exposition of doctrinal belief entitled Qașidat al-nūniyya, and his student, the aforementioned Khayāil Aḥmad Efendi, completed a Turkish commentary on that work, entitled Sharh qașídat al-nūniyya, Kemālpaşazāde's treatise was likely informed by all three of the aforementioned works and meant to definitively settle such debates within an Ottoman context. ${ }^{33}$ It also appears likely that Kemālpaşazāde intended his contribution to better delineate divergences between Ash'ari and Maturidi belief systems in order to more effectively promote the latter as reflecting Ottoman imperial identity. The conversation between these four texts delineating doctrinal belief suggests that one of the legacies of Ottoman Sunnism was to rescue Maturidi distinctiveness from its earlier blurring with Ashari beliefs under what Mehmet Kalaycı has characterized as the "Rāzī framework" dominat-

\footnotetext{
29 Bebek, Hayâlî 3-5.

$30 \quad$ Yazıcıoğlu, Le kalām 82.

31 Dalkıran, İbn-i Kemal 77-79, citing Kemālpaşazāde, Risālatal-Ikhtilāf 57-6o; Kalaycı, Eşarilik ve Maturidiliği 127-129.

32 Berger, Interpretations 697; Badeen, Sunnitische Theologie 10-24.

33 Yazıcıoğlu, Le kalām 71-83; Bebek, Hayâlî 3-5; Yazıcıoğlu, Hızır Bey 413-415.
} 
ing ninth/fifteenth-century Ottoman letters. ${ }^{34} \mathrm{~A}$ century after Kemālpaşazāde's contribution, the Indian Naqshbandi Shaykh Ahmmad al-Sirhindī (d. 1034/1624) seemingly confirmed Maturidi success by arguing that even though both doctrines are properly Sunni, one comes to prefer Maturidi over Ash'ari positions after contemplating their arguments more deeply. Although he credited alAsh'arī with introducing 'aql proofs to discussions of belief, al-Sirhindī conceded that the difficulty of such contemplations had emboldened religion's enemies and driven them on the path to Salafism. However, in his own day, those interested in the light of God's prophecy followed the ahl al-haqq (people of verity) - which he associated with the Maturidi doctrine. ${ }^{35}$

Yet another middle-period trend that shaped Ottoman Sunnism was a drive for certainty in both religious belief and the legal consequences of such belief. Several fifth/eleventh- to eighth/fourteenth-century scholars, including Fakhr al-Dīn al-Rāzī, Sayf al-Dīn al-Āmidī, and Sa'd al-Dīn al-Taftāzānī, who also came to play a prominent role in the Ottoman kalām curriculum, strove to have the study of Islamic jurisprudence ( figh) and its sources (ușül al-figh) be treated as science according to the standards of Aristotelian theory. Loosely related to al-Ghazālī's and Fakhr al-Dīn al-Rāzì's integration of falsafa methodology into kalām discourse, these scholars treated the reconfigured kaläm as an external corroboration of the four accepted sources of Islamic jurisprudence. Demonstrating just how far theological disputation had progressed, from a shunned source of doubt to a philosophically rigorous source of certainty, kalām proofs for the existence of God and accuracy of Quranic revelation, the first and primary source of figh, were taken to subsequently ensure the accuracy of the remaining three figh sources (hadith, consensus, and analogy). In effect, by striving for certainty in legal theory via demonstrative proofs as opposed to what they presented as the earlier reliance on taqlid (imitation), such scholars tried to render legal practice more "scientific," and thus more persuasive. Treating ușūl al-figh sources as scientific proofs from which legal assessments $(a h k \bar{a} \bar{m})$ can then be drawn, such scholars, particularly Ṣadr alSharīa (d. 747/1346), laid the groundwork for later legists to claim religious certainty in their interpretations of beliefs and subsequent legal certainty in specified punishments for countering those beliefs. ${ }^{36}$ By the late ninth/fifteenth century, Ottoman scholars further explored and extended the implications of this trend by arguing that jurists' opinions qualified as fulfilling the requirements

34 Kalaycı, Mâtürîdî-Hanefî aidiyetin 26-34.

35 Tosun, Mâtüridîyye ve tasavvuf ilişkisi 52.

36 Atçıl, Greco-Islamic philosophy 33-54. 
of legal certainty. Not surprisingly, the culmination of this trend rendered religious belief increasingly prominent and legally relevant, additionally threatening public figures who refused to conform, as well as communities whose actions were considered to display external signs of internal unbelief $(k u f r) .{ }^{37}$

As Ottoman Sunnism was just taking shape, kalām had evolved well beyond the founders' (mutaqaddimūn) emphasis on revealed knowledge of the earlier centuries, which tended to emphasize fairly straightforward interpretations of scriptural proofs, according to madhhab affiliation. Following al-Ghazālì's and Fakhr al-Dīn al-Rāzìss reformulation of the discipline, and the contributions of several subsequent scholars, kaläm had evolved into a complex, comprehensive, and philosophically informed discourse, which provided doctrinal certainty and external legal corroboration for the opinions of state-affiliated ulama. Of course, an alternative view advocated for keeping philosophical methodology and discourse out of kalām and concentrating purely on broader religious doctrine ( $u s \underline{u} l$ al-dìn) verified via naql revealed proofs. Supporters of this view included the Hanbali scholars Ibn Taymiyya (d. 728/1328) and his student Ibn Qayyim al-Jawziyya (d. 751/1350), as well as the Mamluk scholar Jalāl al-Dīn al-Suyūtī (d. 911/1505). ${ }^{38}$ While this alternative view might appear to represent a narrow-minded reliance on revelation, it might also be seen as resisting the ongoing expansion of theological discourse into matters and disputes that went well beyond the "original intent" of prophetic revelation.

Generally speaking, by the end of the ninth/fifteenth century, both the Maturidi and Ash'ari schools had mutually recognized each other's legitimacy as Sunni positions, the Shirazi school(s) had successfully rehabilitated mystically inclined rational philosophy, scholars continued to search for certainty in religious belief, and some scholars articulated arguments rendering kalām legally relevant. The integration of philosophical discourse into theology, coupled with the search for certainty and the recharacterization of ahl al-sunna as accepting both Maturidi and Ash'ari positions while rejecting others, eventually led to the political use of kaläm as a form of state legitimation, with deadly consequences for some. As first Mollā Luṭfì (d. 9oo/1494) and later Mollā Kābıż (d. 933/1527) were to discover, once state-backed scholar-bureaucrats had moved beyond certainty in religious belief to rendering such correct belief legally actionable, kalām became a dangerous discourse for those publicly insisting on views considered beyond the pale. ${ }^{39}$

37 Al-Tikriti, Kaläm in the service 131-149.

38 Atçl, Greco-Islamic philosophy 51; Özervarl, Theology in the Ottoman lands 583; Hoover, Hanbalī theology 625-648.

Ocak, Osmanlı toplumunda zındıklar 203-25o; Erünsal, Molla Lütfi 37-54. 
As the imperial madrasa infrastructure and curriculum reached its full articulation by the middle of the tenth/sixteenth century, a recognizable Ottoman kaläm branch had emerged. While this branch is usually described as simply "Maturidi," it might be more accurate to follow M. Sait Özervarlı's lead in characterizing this as a "new synthesis." 40 This new synthesis emerged together with Ottoman Sunnism, maintained continuous scholarly dialogue with classic works of the Ash'ari school while largely defending Maturidi positions, absorbed the methodology and rhetoric of what is usually described as the "Shirazi school" of hikma-driven philosophy into theological dialogue, and had grown both legally relevant and politically powerful — at least in those areas under Ottoman sovereignty.

One emblematic participant in the small circle of imperial elites who engaged in a broad range of political and scholarly discourse, including kalām disputation and uṣül al-dīn commentary, and thus helped define Ottoman Sunnism, was Şehzāde Korḳud (d. 919/1513). In the popular literature on Ottoman history, he is more commonly recalled (when remembered at all) as a complaining, compromised, and weak prince who proved completely unable to compete against his courageous and decisive younger half-brother, Sultan Selīm I (r. 918926/1512-1520). In reality, Korkud's political biography was far more complex than the image promoted by subsequent court historians, and his gradual erasure from the pantheon of Ottoman letters is itself worthy of study. ${ }^{41}$

In preparation for a long-anticipated struggle to succeed his father Bāyezīd II (r. 886-918/1481-1512), throughout the first decade of the tenth/sixteenth century Korkud strove to portray himself as a well-rounded candidate who was intellectually and ethically prepared to assume the role of an ideal Ottoman and Islamic ruler. He was not alone in such endeavors. As Christopher Markiewicz has demonstrated, Idrīs-i Bidlīsī (d. 926/1520), during the same decade, strove to portray first Şehzāde Aḥmed (d. 919/1513), then Şehzāde Şehinşāh (d. 917/1511), and finally Selīm each as respective heirs apparent to the "viceregency of God" (khiläfa-yi rahmmān̄̄ $).{ }^{42}$ While each of these four surviving sons of

40 Özervarl, Theology in the Ottoman lands $568,576$.

41 For Korḳud's life and works, see Al-Tikriti, Şehzade Korḳud. For summaries of Şehzade Korḳud's life, see Emecen, Korkut, Şehzade 205-207; Gökbilgin, Korkut 855-86o; Gökbilgin, Korḳud 269; and Uzunçarşıll, II'inci Bayezid'in oğullarından 539-6oı. 
Bāyezīd II could by 917/1511 count on various personal strengths and centers of support, only Korḳud is credited with authoring treatises that laid out opinions on matters of faith, legitimacy, and correct governmental practice.

Turning the "publish or perish" mantra somewhat on its head, the largely forgotten Korkud proved more prolific, engaged, and successful in different realms of belles-lettres than any other Ottoman royal, ever. He has also resisted neat classification as either amìr (commander) or 'älim (scholar), as his other accomplishments in the fields of poetry, musical composition, calligraphy, and other fine arts might be considered consistent with either category. İsmail Hakkı Uzunçarşılı treated Korḳud as something of a weak prince who pursued a side interest in Arabic legal treatises - a view largely consistent with that promoted by Ottoman historians in the decades following Korkud's death. ${ }^{43}$ More recently, Ahmet Hamdi Furat considered Korkud a proper Shafi'i faqīh who happened to be an Ottoman royal, as opposed to a fully competitive prince who nearly succeeded Bāyezìd II. ${ }^{44}$ Why did a prince in the midst of a highly politicized and dangerous succession intrigue also engage in seemingly obtuse questions of theological discourse? As Lutz Berger has suggested, "theological knowledge was part and parcel of the academic credentials of scholars and therefore their social standing."45 Perhaps Korkud hoped to persuade potential supporters that he was the most worthy candidate to succeed his father Bāyezìd by engaging directly in such matters as a participating 'âlim, as opposed to merely patronizing such scholarly works as an amir.

While Korkud's oeuvre is impressive for a royal figure normally obliged to follow the career track of a military sovereign, there remains a question of authorship. His extant correspondence, poetry, calligraphy, and musical compositions raise no particular red flags concerning authorship, no more than with any other historical figure living five centuries ago. However, his Arabic treatises are another matter. He is credited with as many as seven discursive treatises and a collection of legal opinions, four of which remain extant within Süleymaniye Library's Aya Sofya collection. Three of these extant texts exhibit a high level of scholarly Arabic, free from obvious mistakes and in line with the conventions of the time. ${ }^{46}$ One of those texts analyzed here, Da'wat alnafs al-tāliḥa, survives in three manuscript copies. The draft version includes a prefatory statement attributing the text to Korḳud while stating that an oth-

43 Uzunçarşıllı, II'inci Bayezid'in oğullarından 539-6o1.

44 Furat, Osmanlı hânedanında 193-212.

45 Berger, Interpretations 701.

46 However, Prof. Wadad Kadi once suggested that the Arabic of Korḳud's Da'wa was not native. 
erwise unknown scholar, 'Abd al-Salām b. Muhammad al-Anșānī, dictated the text, on behalf of "the sultan of scholarship and scholar of his era," Korkud. ${ }^{47}$ The fourth extant text, Wasilat al-ạ̣bāb, which the prince addressed directly to his father as an extended and private explanation of his sudden 915/1509 departure for Mamluk Egypt, is riddled with basic Arabic grammatical errors. ${ }^{48}$ Comparison of all known copies of these texts attributed to Korkud suggests multiple possibilities in terms of authorship. Perhaps Korkud authored all texts attributed to him but had al-Anșānī dictate (and edit) the draft version of al$D a^{\prime} w a$ on his behalf. Alternatively, perhaps al-Anșānī was the ghost writer of $a l-D a^{2} w a$, or perhaps it was a group effort by more than one scholar resident at Korkud's court working under the prince's direction. What is certain is that there is great discrepancy between the levels of Arabic competence displayed in Da'wat al-nafs al-țaliha and in Wasilat al-ahbāa b and that all of the works were claimed by, and credited to, Şehzāde Korḳud.

Through these texts, Korkud presented his views forcefully, his argumentation reflecting the worldview, expertise, and literature of Ottoman ulama around the turn of the tenth/sixteenth century. While many of his views were emblematic of this stage in the formulation of Ottoman religious identity, they were not entirely consistent with what came to be adopted. Notably, Korkud preferred the Shafi'i madhhab, even while the Ottoman madrasa system of his own day had already established a definitive Hanafi preference. Similarly, he condemned Ibn 'Arabī (d. 638/1240), whom Kemālpaşazāde (d. 940/1534) rehabilitated after Korkiud's death, following Sultan Selīm's public visit to and restoration of Ibn 'Arabỉ's tomb during the 922/1516 Syria campaign. ${ }^{49}$

Korkud's intellectual journey is itself somewhat indicative of broader trends in ninth-to-tenth/fifteenth-to-sixteenth-century intellectual thought. Educated primarily by Anatolian-based scholars who were in turn heavily influenced

47 This copy is probably the same as that said by Uzunçarşılı (II'inci Bayezid'in oğullarından 596-597) to be owned by the book merchant Raif Yelkenci. Cornell Fleischer (From Korkud to Mustafa Āli $67-77$ ), the first modern scholar to analyze this text in depth, used a microfilm of this copy, also said to have once been owned by the prominent Ottoman historian M. Tayyib Gökbilgin. I am indebted to Prof. Fleischer for providing me with a microfilm of this copy. Korḳud, Da'wat al-nafs al-țaliha, Ms Gökbilgin, 423. Unless otherwise indicated, all citations from this text refer to the presentation copy, Süleymaniye Kütüphanesi, Ms Aya Sofya 1763 .

48 For an extensive analysis of this text and Ḳorḳud's Egypt visit, see Al-Tikriti, The hajj 125146.

49 Dalkıran, İbn-i Kemal 182-184; Şeyh Mekki Efendi and Ahmed Neyli Efendi, Yavuz Sultan Selim'in emriyle. For Korḳud's view, see Şehzāde Korḳud, Da'wat al-nafs al-țāliha 233b235b. 
by Timurid and Aqqoyunlu scholarly circles, Korḳud also maintained a strong Egypt connection toward the end of his career. He requested theological advice from the famous Cairene scholar Abū Yahyā Zakariyyā al-Anșāin (d. 926/1520), 50 and relied on the aforementioned Egyptian shaykh with the same family name, 'Abd al-Salām b. Muhammad al-Anșārī, to both dictate the rough draft of his magnum opus and negotiate his 1510 return from exile in Cairo. ${ }^{51}$ To better understand Korḳud's personal journey and subsequent contribution to an emergent Ottoman Sunnism, let us now examine his educational formation, intellectual circles, his oeuvre as a whole, and some of the arguments contained in two of his most prominent treatises.

\section{A Palace Education}

Korkud's educational formation combined a fairly typical Anatolian education, dominated by post-Timurid Iranian and Central Asian influences, and a somewhat less typical current characterized by Egyptian Ash'ari influences. ${ }^{52}$ His father Bāyezìd's Amasya court retained teachers, calligraphers, artists, and scholars, several with strong connections to Iran or other eastern lands. These teachers included Mollā Ṣalāḥu'd-dīn (fl. 881/1476), Amasyalı Hațịb Ḳāsım (d. ca. 926/1520), Mīrim Çelebi Maḥmūd (d. 930/1524), Mu'arrifzāde, and Amasyalı Shaykh Ḥamdullāh (d. ca. 926/1520). ${ }^{53}$ Several of those known to have been resident at Bāyezīd's Amasya court should have exerted influence on Korḳud's education. However, as little was recorded about Korkud's childhood in Amasya per se, the only direct connection made between him and these teachers comes from a twelfth/eighteenth-century biographical notice stating that as a child he had studied with the Bukhara emigré and first significant Ottoman master calligrapher, Shaykh Ḥamdullāh of Amasya, who has been credited with designing a definitively Ottoman script. ${ }^{54}$

50 His full name was Abū Yahyā Zakariyyā Muhammad b. Aḥmad al-Anșārī al-Shāfiì. For biographies of al-Anșāīī, see Ingalls, Recasting Qushayrī's Risāla 93-120; Geoffroy, Le Soufisme 517-518; Özel and Kallek, Zekeriyyâ el-Ensârî 212-215. I thank Matthew Ingalls for clarifying certain points of al-Anșārī's biography.

$51 \quad$ Al-Tikriti, The hajj 128.

$5^{2}$ For other preconquest Ottoman intellectual connections with Arab lands, see Pfeifer's and Terzioğlu's articles in this volume.

53 Mecdî, Hadâiku'ş-şakâik 197-198, 212-213, 338-339, 513; Kappert, Die Osmanischen Prinzen 45-67; Uzunçarşılı, İlmiye teşkilâtı 145.

54 Müstakīmzāde, Tuhfe-i haț̣ațtīn 368; Osborne, Letters of light 44-53; Sohrweide (Dichter und Gelehrte $275^{-276}$ ) counted Shaykh Ḥamdullāh as one of many eastern scholars who 
There is evidence that one of Bāyezìd's oldest and closest companions during his posting in Amasya and throughout his life, Amasyalı Mü’eyyedzāde 'Abdu'r-raḥmān Çelebi (86o-922/1456-1516), ${ }^{55}$ played a mentoring role for Korkud. Mü'eyyedzāde was a talented scholar and litterateur who was forced to flee Anatolia in 883/1479 following an execution order from Sultan Mehmed, ostensibly for supplying his son Bāyezīd with opium. ${ }^{56}$ After a brief stop in Aleppo, Mü’eyyedzāde studied in Shiraz under the prominent Ash'ari scholar and Shirazi school of philosophy paragon Jalāl al-Dīn Dawānī while waiting for events to turn more propitious in Istanbul. ${ }^{57}$ Soon after Bāyezīd rose to power, this young scholar and boon companion followed the new sultan to Istanbul. Although not exceptionally prolific on his own account, Mü’eyyedzāde was a star student of Dawānī, frequented the same circles as the foremost religious scholars of his own generation, and guided many of the empire's religious policies from the 88 os/148os right up to his execution in $922 / 1516$, both as Bāyezīd II's close companion and later as first Anadolu and then Rumeli kā dì asker (military judge). A powerful minister and scholarly practitioner, he boasted a personal library that was reportedly one of the largest ever seen in Istanbul, the inventory of which continues to provide a useful source for early modern Ottoman intellectual history. ${ }^{58}$

Mü'eyyedzāde once responded to a personal request by sending Ḳorḳud a treatise addressing "complex issues of kalām," accompanied by a versified Arabic introduction offering exaggerated praise of the prince. As no scholar named the treatise, it has not yet been identified and may no longer exist. ${ }^{59}$ Although Korkud never referred to Mü'eyyedzāde directly, such personal ties, recalled in the tezkire literature several decades after the fact, suggest that this powerful minister, scholar, and close friend of his father informed Korḳud's views and

greatly influenced Ottoman letters in its formative ninth-tenth/fifteenth-sixteenth centuries.

55 Kemālpaşazāde (İbn Kemâl, Tevârīhh-i Âl-i Oșmân vi, 5-6) devoted a brief panegyric passage to Mü’eyyedzāde during his discussion of Bāyezīd's preaccession court, demonstrating his importance and proximity to Bāyezīd, at least when Kemālpaşazāde wrote the passage, ca. 917/1511.

$5^{6} \quad$ For Bāyezīd's response to his father, apologizing for not carrying out the execution order and promising to refrain from future opium consumption, see TSA E6366/1. Uzunçarşll, Fatih Sultan Mehmed'in ölümü, 474-475.

57 See Pfeiffer, Jalāl al-Dīn al-Dawānīs 284-331.

58 Taşköprüzade, al-Shaqā’iq 290-294; Menzel, Mu’ayyad-zāde 272.

59 Mecdî, Hadaiku'ş-şakaik 310; Taşköprüzade, al-Shaqā’iq 294; Hoca Sa'dü'd-dīn, Tāc üttevārīh ii, 556; Kātib Çelebi (Kashf al-zunūn iii, 433, \#6302) referred to the work as simply "a treatise on kaläm." 
scholarly positions. Similarly, Mü'eyyedzāde's active engagement in the field of kalām suggests an ongoing discussion within high imperial circles on matters of theological import and their role in society.

One teacher, whose court career is at least indicative of the type of intellectual influences that surrounded the young Korḳud in Amasya and demonstrates how Bāyezīd II himself engaged with scholarly Arabic kalām treatises, was Mollā Ṣalāḥu'd-dīn (fl. 881/1476). ${ }^{60}$ Mollā Ṣalāḥu'd-dīn reportedly instructed prince Bāyezīd in Sa'd al-Dīn al-Taftāzānī's commentary on al-Nasafì's creed, Sharh al-Aqä’id (Commentary on the tenets of faith), going so far as to write an explanatory gloss on the text in Arabic for Bāyezìd's benefit. ${ }^{61}$ While Korḳud never cited any of Mollā Ṣalāhu'd-dīn's work, he also studied alTaftāzānì's Sharh al-'Aqā̉id at least as early as his teen years, as he was gifted a copy of it in $890 / 1485 .{ }^{62}$ Proof of his later familiarity with the eminent theologian came when Ḳorkud cited Sharh al-Aqāid along with several other works by al-Taftāzānī over 30 times in his own kalām engaged treatise, Häfiz al-insān. ${ }^{63}$

After Korkud was transferred around 884/1480 from his father's court in Amasya to his grandfather Mehmed II's court in Istanbul, ${ }^{64}$ one of his teachers was Mollā Seyyid İbrāhīm (d. 918/1512). Like other influential figures in Ḳorḳud's youth, Seyyid İbrāhīm had connections to both Iran and Anatolia. A somewhat colorful character, boasting miraculous powers, İbrāhīm's father had been an Iranian notable who had previously emigrated to a village near Amasya. ${ }^{65}$

While the source evidence is somewhat fragmentary for his earliest instruction, it does suggest that the young Korkud was exposed in Amasya and Istanbul to the Iranian and Central Asian influences that were current in his day. Via those teaching at the court, the prince should have been exposed to debates concerning falsafa methodology, the integration of philosophy with kalām, both Maturidi and Ash'ari beliefs, and even miraculous events connected to occult practice.

$60 \quad$ Kappert, Die Osmanischen Prinzen 46, citing Ḥüseyin Hüsāmeddīn, Amasya Tārīhi iii, 232. Hüsāmeddīn, writing in the early twentieth century, rarely cited his sources.

61 Kappert, Die Osmanischen Prinzen 46; Taşköprüzade, al-Shaqā’iq 178-179; Mecdî, Hadâiku'ş-şakâik 197-198.

62 The 1481-1487 gift register (TSA D10o17) records a 1485 delivery of a copy to Korkud.

63 Korḳud, Hāâfiz al-insān 2a-3a, 4a-b, 8a-9b, 14a-15a, 20a-26a, 27a, 32b, 58a, 6oa-61a, 62b65a, 82a, 89a-b, 9ob-91b, 94/2a, 114b, 118b, 124a-b, 129a-b, 137a, 145b-146a, 158b, 16ob, 172b-173a, 187a, 188a, 215a.

64 Gökbilgin, Korkut 856.

65 Sohrweide, Dichter und Gelehrte 276; Taşköprüzade, al-Shaqā̉iq 305-309; Mecdî, Hadâiku'ş-şakâik 319-323. 
Korkud also appears to have maintained a Cairo connection, both politically and intellectually. The origins of this connection remain uncertain, but as an adult Ḳorḳud collaborated extensively with 'Abd al-Salām b. Muhammad al-Anșāin. Described only as an "al-Azhar Shaykh" in Wasilat al-aḥbāb, this scholar played a key role in Korkud's political writings and negotiations from at least 1508 onward. ${ }^{66}$ 'Abd al-Salām might have been related to the celebrated Cairene scholar and mystic Abū Yahyā Zakariyyā al-Anșārī (d. 926/1520), from whom Korkud sought a legal opinion concerning the legal status of concubines. ${ }^{67}$ These relationships suggest a level of intellectual interaction between both Ottoman and Mamluk ulama and umara $\bar{a}$, and since Egypt was famously a stronghold of the Shafi'i madhhab, it might also explain to some extent Korkud's apparent Shafíi affiliation.

\section{$4 \quad$ Following a Curriculum, Starting a Library}

The young Korkud's strong predilection for scholarship was also confirmed by gifts recorded as presented to him in a $890 / 1485$ register, when he was roughly fifteen-sixteen years old, and soon after he had been assigned to his first provincial posting. While all the princes recorded in the gifts register, including Ķorḳud, were gifted falcons, concubines, and slaves, only this scholarly şehzāde was also presented with texts covering a broad range of literary, philosophical, and legal issues. ${ }^{68}$ Of these six texts, one was Nizāaim’s (d. ca. 6o5/1209) poetry quintet, ${ }^{69}$ one was devoted to jurisprudence or governance, ${ }^{70}$ and four were devoted to issues of philosophy and theology. Each of these texts demonstrate the intellectual milieu to which the young prince was exposed growing

$66 \quad$ Al-Tikriti, The hajj 128.

67 Korḳud stated in his Hall ishkāl $(51 \mathrm{~b})$ that he had obtained a fatwa on this topic from "Shaykh al-Islām al-Shaykh al-Qãḍ̂̀ Zayn al-Dīn Abū Yahyā Zakariyyā al-Anșārī-raḍi Allāh 'anhu."

68 According to the gift register (TSA Dioo17, f. 2), on 13 Dhū al-Qa'da 89o/21 November 1485 the following texts were presented to Korḳud's nişāncı for personal delivery to the prince: K. Isfarā̄înī, Sharh-i 'aqā̉id, K. Sharh-i mațāli', K. Hāshiye-i mațāli', Kitāb-i mukhtașar, and K. Khamsa-yı Nizämī.

69 TSA Dioo17. This was his celebrated poetry collection, the Khamsa-yi Nizāmī (Nizâmī’s quintet). Comparison of these poems against his own poetry and scholarship suggests that Korkud studied these five works intensively as part of his advanced education, and that his later literary outputs, which lay beyond the scope of this study, were informed by these master works. Chelkowski, Niz̄āmī Gandjawī 76-81. 
up, although disentangling precisely how certain texts influenced him remains a challenge.

A text addressing either jurisprudence or governance was Kitāb al-mukhtașar (The handbook), a generic title which could refer to several works providing the early modern equivalent of college law textbooks. In his own scholarship, Korkud cited works with the same title by the Egyptian Hanafi jurist Abū Ja far al-Ṭahāwī (d. 321/933), the Baghdad Hanafi jurist al-Qudūrī (d. 428/1037), and the Shafi'i-influenced Maliki jurist al-Shaykh al-Khalīl b. Isḥāq (d. 775/1374). It is equally possible that the title referred to a text recently analyzed by Hüseyin Yllmaz, Mukhtașar fi l-siyāsa wa-umūr al-salțana (Compendium of governance and the affairs of rulership). This anonymous Arabic text was completed early in Bāyezīd II's reign, urging him to follow the lead of his deceased father, Mehmed II, in promoting a devşirme class of trained professionals at the expense of old Anatolian elites. Consistent with the Mamluk tradition of moralistic mirrors for princes, Mukhtasar advocated a more juridical and hierarchical view of correct governance than previous works found in the Ottoman milieu, which tended to be more abstract and lean toward hagiographical presentations of ruler perfection. ${ }^{71}$ Serving as an administrative manual based on older Islamicate examples, this work was capable of providing several of the governance critiques Korḳud later made in his Da'wat al-nafs al-țăliḥa.

The first of four texts likely addressing religious belief, listed as simply K. Isfarāin̄ī (The book of Isfarāīnī), could be one of several works by any of three scholars hailing from Isfarāyīn in Khorāsān. While available evidence does not allow full confirmation of which text the gift register referred to, the topics in which Korkud most engaged suggest that he was likely given the text by "al-Ustādh" Abū Ishāq al-Isfarāīnī's (d. 418/1027) al-'Aqīda (The creed). Covering a wide range of theological questions from an intellectual grandson of al-'Ash'arī, who broke with him on several points as a rationally minded and Mu'tazili-leaning Ash'ari theologian, al-'Aqi'da was one of the foundational texts of kaläm, and clearly worthy of consultation and instruction in the late ninth/fifteenth century. ${ }^{72}$

$71 \quad$ Yilmaz, Caliphate redefined 37-39.

72 Ḳorḳud twice cited "al-Shaykh" Abū Ḥāmid al-Isfarāīnī (d. 406/1016), a jurist sometimes referred to as a "second Shāfici" due to his Ta lī q, a fifty-plus volume commentary on yet another Mukhtașar text, this time a well-known Shafi'i legal manual by al-Muzanī (d. 264/878). Several times Korḳud also referenced arguments made by "al-Ustādh" Abū Isḥāq al-Isfarā̄in̄i in his al-Aqìda (The creed), Ādāb al-jadal (The art of dialectics), and other unspecified texts. Considering that the gifts document only mentioned a single volume, and that Ḳorḳud cited Abū Isḥāq far more than Abū Ḥāmid, it is more likely that the text he was given was one of the two Abū Ishāa qreatises. Korḳud, Da'wat al-nafs al- 
Another text, listed with the generic title Sharh-i 'aqā'id (Commentary on the creeds), can be tentatively identified through Korkud's own citations as Sa'd al-Dīn al-Taftāzānīs Sharh al-'aqāiid, a kalām classic that greatly influenced Ottoman theological study. ${ }^{73}$ Credited with combining and reconciling Ash'ari and Maturidi kalām disputation, al-Taftāzānī's commentary served as an exploration, critique, and philosophical elaboration of the rather brief alAqā̉id text by the Maturidi theologian Najm al-Dīn 'Umar al-Nasafî. ${ }^{74}$ Finally, while Korkud cited all of these scholars, the only Sharh al-Aqāंid he ever quoted by name was al-Taftāzānī's celebrated commentary, which he referred to five times in two of his works. ${ }^{75}$

The final two texts listed on the gift register consisted of a commentary and a gloss on that same commentary. Listed as Sharh-i Mațāli and Hāşsiye-i mațālic, these texts were most likely the Sharh al-Mațālic of Quṭb al-Dīn alRāzī al-Taḥtānī (d. 766/1365) and Hẹashiyyat al-Mațālic by al-Sayyid al-Sharīf al-Jurjānī. Consistent with the intellectual genealogies operative in the postMongol era, these texts were directly related to, and expanded on, a work originally produced by an earlier philosopher. The original work in the chain was Mațāli al-anwār (Ascensions of the illuminations) by Sirāj al-Dīn al-Urmawī (d. 682/1283), a meditation on logic and philosophy by a highly influential and well-traveled scholar. ${ }^{76}$ Quṭb al-Dīn al-Rāzī produced a commentary on the logic section of al-Urmawì's work, entitled Lawāmic al-asrār fì sharh mațālic al-anwār (Luminous mysteries in a commentary on the ascensions of the illuminations), which became known simply as Sharh al-Mațälic This text and its

țāliha 47a, 214a, 218b; Hall ishkāl al-afkār, 33b, 53b-54a; Hāâz al-insān, 2b, 29b, 40a, 41a, 65b; Madelung, al-Isfarāyīnī 107-108; Yavuz, Isferāyīnī, Ebū Ishāk 515-516; Heffening, alMuzanī 822 .

73 The text may also have been Khayāli Ahmad Efendi's (d. 874/1470) commentary on the same al-Nasafì text, with the same title. Khayālī's text would have been more current, and was also to become an integral part of the Ottoman madrasa curriculum, but as it was not nearly as well known, if it were this text, it should have carried an additional qualifier in its title. At least two other scholars, the renowned theologian Sayyid al-Sharif al-Jurjānī and the relatively unknown Aḥmad Jamāl al-Dīn al-Qūnawī (d. 731/1331/2) completed works that were also entitled Sharh al-'aqā'id. However, al-Jūrjānī's commentary on 'Aḍud al-Dīn al-İjī's al-'Aqā̉id and al-Qūnawī's on al-Ṭaḥāwī's al-'Aqā̉id were also not nearly as widespread as al-Taftāzānī's work. TSA D1oo17; Tritton, al-Djūrdjānī 6o2-6o3; van Ess, al-Īdjī 1022; Görgün, Īcī, Adudüddin, 410-414; Gümüş, Cürcānī, Seyyid Şerif 134-136.

74 Würtz, Islamische Theologie im 14 Jahrhundert; Spannaus, Theology in Central Asia 587588.

75 Ḳorḳud, Da wat al-nafs 239b; Hāấz al-insān 2b, 114b, 118b, 16ob; Madelung, al-Taftāzānī 8889; Wensinck, al-Nasafĩ 968-969; Yavuz, Nesefì, Ebü'l-Muīn 568-570.

76 Marlow, Sirāj al-Dīn Urmavī 279-313. 
author were sufficiently renowned that al-Jurjānī traveled from his Astarabad home to Herat to study the text in person with the elderly al-Rāzì. Later, while in Cairo instructing students on al-Rāzī's Sharh, al-Jurjānī produced his own gloss on that commentary, which he entitled Häshiyyat 'alä sharh Mațāli' al-anwār (A gloss on the commentary of the ascensions of the illuminations). ${ }^{77}$ While Korkud chose not to cite any of these aforementioned texts by name in his own surviving works, he listed al-Urmawī as one of the favored scholars in his suggested "third doctrine," quoted other works by al-Jurjānī several times, and criticized madrasa students of his day for reading only al-Jurjānī's Hāshiyya and one other theology work — suggesting that al-Jurjānì's text played a prominent role in Ottoman scholarly discourse by the end of the ninth/fifteenth century. ${ }^{78}$

Turning from the prince's intellectual formation to his own scholarly output, Korkud contributed two lengthy texts, which extensively explored issues of kalām disputation, ușül al-dīn, and their applicability to social issues of his day. Through these texts, he exemplified the range of mainstream thought within the Ottoman elite and left his mark on the evolution of Ottoman Sunnism.

In his voluminous 913/1508 Da'wat al-nafs al-țāliḥa ilā l-a'māal al-șăliḥa, bil-ayāt al-zāhira wa-l-bayyināt al-bāhira (An errant soul's summons to virtuous works, through manifest signs and splendid proofs), ${ }^{79}$ Korkud articulated specific critiques of imperial administrative practice, as well as general views of correct ethical living. Meditating first on the inevitability of death and the finality of the hereafter, he devoted this most ambitious of his treatises to renouncing his candidacy to the throne while addressing various aspects of what he considered disregard for shar $\bar{\imath}$ ethical considerations within Ottoman domains. ${ }^{80}$ His primary thesis was that no individual could both serve as an

77 An Ottoman scholar named 'Abdü'l-kerīm Efendi, who flourished during the reign of Murād II (r. 824-855/1421-1451), produced another work entitled Hāshiyyat al-mațālic. Since the reception of this scholar's gloss was modest at best, it appears likely that Korḳud's gifted work was al-Jurjānī's text. Pourjavady, Philosophy in early Safavid Iran 2; Gümüş, Seyyid Şerif Cürcānī 86-88, 115-116, 148-149; Gümüş, Cürcānī 134-136; Țāhir, Oșmānlı Müellifleri, i $35^{2}$.

78 Korkud, Da'wat al-nafs 221a.

79 Title as provided in frontispiece. This translation of the title follows Fleischer.

8o Korkud consistently used the term shar', not sharīa, which supports Wilfred Cantwell Smith's argument that the term sharía came into common use only in later centuries. Smith, The concept of shari'a $581-602$. 
effective amïr (prince) in his corrupt times (or any time) and still hope to attain a pleasant afterlife. By criticizing what he saw as critical problems in Ottoman governance, Korkud's al-Da'wa implicitly provided his ideal vision for a wellfunctioning society. While Da'wat al-nafs al-țaliha can in no way be classified as a kalām text, it provided strong arguments on the madrasa curriculum of the time, as well as kaläm's role in protecting society from dangerous or subversive trends and movements.

At roughly the same time that Korkud was working on al-Da'wa, he (and his team of scholars) was also working on Hāfiz al-insān 'an lāfiz al-ìmān wa Allāh al-hādì ilā șirāt al-jinān (The individual's protector from faith's rejector, as God is the guide to the heavenly paths). ${ }^{81}$ This text was never completed, with the sole surviving copy bringing together 96 folios of a presentation draft, 16 folios repeating, in draft form, the end of the presentation draft, and a further 113 folios of draft copy, which ends in mid-thought. Since the text was referred to in al-Da'wa, Korkud had clearly begun working on Häfiz al-insān by 913/1508 and failed to complete it before his death in 919/1513.

With its strident arguments justifying secular enforcement and legal expansion of shar'-sanctioned punishments (ahkām) for apostasy, Hääiz al-insān provided a comprehensive kaläm justification for the legally sanctioned takfir of certain groups or individuals found guilty of exhibiting external signs of internal absence of faith. While not solely devoted to kaläm debates, most of this text addressed kaläm discourse and methodology, using the discipline as a basis to advocate for a more engaged state policy vis-à-vis religious belief. Together, these two texts demonstrate the rhetorical power of kaläm discourse to promote policy positions justified as strengthening dinn ü devlet (religion and state).

Throughout Da'wat al-nafs al-țăliha, Korḳud presented arguments by which, taken together, he intended to define the ideal characteristics of the empire's religious identity. He opened $a l-D a^{\prime} w a$ by first reflecting at length on the meaning of the afterlife, "purchasing this world with the other one," and the concept of the "bankrupt one" (muflis). To do so, he opened with several Quranic verses and prophetic hadiths about Judgment Day, which themselves constituted something of an argument, an abstract outline for the entire text, and a demonstration of the persuasive power of revealed knowledge..$^{82}$ Advocating

81 MS Aya Sofya 2289. Here referred to as Hāafiz al-insān. I thank Urs Göskin for his incisive comments concerning this text.

82 Korkud, Da'wat al-nafs 1a-4a, citing Q 3:185, 21:35, 29:57, 55:26, 28:88, 101:6-11, 99:7-8, 79:35-41, 89:27-30, 51:56, 83:4-5, 102:8, 35:5-6. 
on behalf of the poor and oppressed, in this introductory section he signaled a facility for $n a q l$ argumentation by employing a string of revealed proofs in his appeal for ethical rule. In addition, he pointedly used the term ahl al-sunna wa-l-jama $\bar{a}^{\prime} a$ when countering Mu'tazila arguments concerning the fate of the muflis, thus demonstrating something of a "Sunni consciousness" in his rhetorical selection.

Framing his resignation from ruling candidacy as an ethical imperative, Korkud next explained how one could never simultaneously enforce the dictates of both shar' (religious ethics) and the 'urf (imperial legal convention) of his time as a sovereign ruler. ${ }^{83}$ Nodding toward his political agenda, he implicitly promised to elevate the status of those he considered shar'-minded ulama, while equally promising to purge those corrupted ulama guilty of currying favor at court-presumably referring to those scholar-bureaucrats most responsible for establishing the nascent madrasa curriculum that would come to define Ottoman Sunnism.

Following the lead of the multiple Ash'ari influences during his education, and consistent with the near merger of Maturidi and Ash'ari views in the course of the ninth/fifteenth century, in Da'wat al-nafs al-țäliha Korkud quoted over 2o pages from Tāj al-Dīn al-Subkì's (d. 771/1370) Mu'ìd al-ni'am to describe how he defined and delineated an ideal religious identity. In one section, al-Subkī summarized how the legal madhhab factions grew hostile to each other, until eventually the ahl al-sunna wa-l-jamāa $a$ grew persuaded by al-Ash'arìs path, as laid out in the various ' $a q \bar{a} \dot{i}$ id texts. After that, the Sunni groups came to include the enlightened ones among both the Hanafi and Shafi'i, all of the Maliki followers, and the best of the Hanbali. Concurrently, some of the Hanafi and Shafi'i adherents followed the Mu'tazila, while some of the Hanbali turned toward the mujassima (anthropomorphists), neither of which should be considered Sunni. Tracing Mu'tazili mistakes back to their origin during the reign of caliph al-Ma'mūn (r. 197-218/813-833), al-Subkī rejected those who condemned others for making false statements without care and reflection, based on simplistic and preliminary external proofs. To demonstrate his point, he related an anecdote whereby al-Ma'mūn made a series of outrageous statements, which turned out to be truthful following clarification. ${ }^{84}$

The quoted al-Subki passage then urged the Sunni ulama to unite and continuously oppose those whom he characterized as factionalists, defined as those who attack Islam, oppose the two shaykhs Abū Bakr and 'Umar, and cast

83 Korḳud, Da'wat al-nafs 4a-29a.

84 Ibid. 215b-216b, 251a-252a. 
down 'Â'isha. As he saw it, fighting against those who defame the Quran is a duty, so much so that each and every believer must engage with them. In addition, they should actively engage in proselytizing among Jews and Christians, instead of passively accepting their conversion. ${ }^{85}$

Korkud was broadly sympathetic to the postclassical (muta'akhirūn) forms of theological disputation, which had successfully integrated falsafa methodology following Fakhr al-Dīn al-Rāzī's contribution. However, like many others of the era, he was exceedingly vigilant against the threat of faläsifa's (philosophers) conclusions coming to dominate kaläm discourse and, thus, undermining what he saw as correct usūl al-dīn doctrines. Accordingly, Korḳud provided another extended quote of al-Subkī that condemned the faläsifa, those who had mixed kalām from the theologians with kalām from the falāsifa, Nașir al-Dīn al-Ṭussìs branch of kalām argumentation, and the Mu'tazili theologian al-Zamakhsharì's (d. 538/1144) al-Kashshāf - which Ḳorḳud claimed that many Ajam (i.e., Iranians) read. ${ }^{86}$ Having specified all the areas within and between falsafa and kalām discourses that were to be condemned, Korḳud cited alSubkīs validation of al-Ghazālīss and Fakhr al-Dīn al-Rāzī's earlier use of falsafa methodology to counter their conclusions and defend ahl al-sunna doctrinal integrity. In this same passage, al-Subkī spoke out directly against those philosophically inclined scholars in his own day who referred to themselves as the "wise ones" (hukamä). Following al-Subkî’s lead, Korḳud argued forcefully that the only ones who should engage with the falāsifa, effectively heretics who undermine religious belief from within the community, are those who are fully trained in the branches of figh, cannot be misled by heretical (malähida) beliefs, and refuse to mix kaläm with falsafa in a way that privileges falāsifa doctrinal conclusions. ${ }^{87}$

In Hāfiz al-insān Korḳud similarly condemned the introduction of epistemological doubt due to the mixture of falsafa and kaläm (at kaläm's expense), labeling hikma (wisdom) the most indecent discipline afflicting Ottoman and Ajamı̄ ulama. He specifically rejected teaching al-Hidāya (The guidance) and some of the leading commentaries on it, as these texts made students peripatetic and led to the removal of their beliefs, as well as their incarceration in the prison of error. This statement likely referred to the philosophical work Hidāyat al-hikma (Wisdom's guide) by Athīr al-Dīn al-Abharī (d. 66o/1262), or the commentary on that work by the contemporary logician Mìr Husayn

85 Korkud, Da'wat al-nafs 216b-217a.

86 For more on al-Zamakhsharī, see Versteegh, al-Zamakhsharī 432-434.

87 Korḳud, Da'wat al-nafs 217a-219a. 
al-Maybudī (d. 9o9/1504), a student of Dawānī whom Shah Ismāīl (d. 930/1524) had executed. ${ }^{88}$ As Korkud explained in a lengthy section commenting on Fakhr al-Dīn al-Rāzìs views on perception, only revealed knowledge (naql), not rational speculation ('aql), can lead to certainty among the masses concerning the nature of the divine. Since pure rationalism ultimately depends on perception, which is inherently flawed and subjective, one must judiciously combine the two sources of knowledge, as Fakhr al-Dīn al-Rāzì had done. ${ }^{89}$ Taken together, in these two texts Korkud appears to have been speaking out against what modern scholars have characterized as the "Shirazi school," or perhaps just the branch that was in the process of becoming the Twelver Shi' $i$ offshoot of that school, when he was working on the texts between 914/1508 and 919/1513. He seems to have found their emphasis on hikma (wisdom) as a ruling principle, which was a highly popular motif at that time, to rely far too much on 'aql at the expense of naql.

Toward the end of $H \bar{a} f i z$ al-insān, after a passage analyzing the impediments to certainty one might face relying exclusively on either reason or tradition, Korkud asserted the existence of, and his advocacy for, a "third doctrine" (mad$h$ hab), which accepted kaläm as the methodology for reaching legal certainty in judging kufr and in clarifying the importance of ritual acts such as prayer, almsgiving, and pilgrimage. Those scholars and their works, which he listed as belonging to his ideal "third madhhab," included:

Fakhr al-Dīn al-Rāzī (d. 6o6/1210), in Nihāyat al-'uqūl, al-Arbaīn, and al-Mahșūl;

Sayf al-Dīn al-Āmidī (d. 631/1233), in Abkār al-afkār;

Sirāj al-Dīn al-Urmawī (d. 682/1283), in al-Taḥsill;

'Aḍud al-Dīn al-Ījī (d. 756/1355), in al-Mawāqif;

Tāj al-Dīn al-Subkī (d. 771/1370), in Jam' al-jawāmi';

Sacd al-Dīn al-Taftāzānī (d. 793/139o), in Sharḥ al-maqāṣid; and

Badr al-Dīn al-Zarkashī (d. 794/1392), in Sharh jam` al-jawāmi .90

Korkud argued that these scholars all agreed on the idea that individuals' utterances convey certainty concerning the legal repercussions of scripture-and obedience thereof. As Korkud saw it, this favored group provided the correct medial position between extremist advocates for 'aql and naql, respec-

88 Korḳud, Hāafiz al-insān 48a-b; Pourjavady, Philosophy in early Safavid Iran 35-37; [AlAbharī and al-Maybudī], Commentary upon guidance.

89 Korḳud, Hāfiz al-insān 7ob-82a.

$90 \quad$ Ḳorḳud, Hāfiz al-insān 186b-188b. 
tively, between those whom he believed undermine din from within by mixing kaläm with falsafa on one hand and the Hanbali mujassima literalists on the other.

While all the scholars Korkud listed — all Ash'ari affiliates-were known in Ottoman madrasa circles, they were not all taught equally widely. Korkud's favored al-Subkī text Jam' al-jawāmi', and al-Zarkashī's commentary on it, never found a prominent place in the Ottoman madrasa curriculum, perhaps because Mamluk Ash'ari works became dispensable after Kemālpaşazāde and others more clearly delineated differences between Maturidi and Ash'ari thought. The inclusion of Sirāj al-Dīn al-Urmawì's al-Tahṣill is something of an odd choice, as al-Urmawī's Mațālic al-anwār was condemned by al-Jurjānī for marginalizing kalām as a secondary science interested only in God's essence. ${ }^{91}$ As his al-Tahṣill was an abridgment of Fakhr al-Dīn al-Rāzīs al-Mahṣūl, covering the principles of jurisprudence, perhaps Korkud felt the text supported his drive to achieve legal certainty in judging kufr. ${ }^{92}$ Similarly, Sayf al-Dīn al-Āmidī was highly critical of Fakhr al-Dīn al-Rāzī, although perhaps solely due to professional jealousy. ${ }^{93} \mathrm{~A}$ fascinating list, this chain of supposedly like-minded scholars excluded al-Ghazālì (d. 505/1111), who was particularly known for his arguments paving the way for rendering scripturally based opinions legally relevant. ${ }^{94}$ It also excluded other notable figures who were studied widely in Ottoman madrasas and considered important contributors to the movement of tahqīq (verification), ${ }^{95}$ such as al-Ghazāilì, Imām al-Ḥaramayn al-Juwaynī (d. 478/1085), and al-Sayyid al-Sharīf al-Jurjānī (d. 817/1413). ${ }^{96}$ While his list did not correspond entirely with what became the Ottoman madrasa canon in kaläm, it might be seen as an early roster of muhaqqiqūn scholars, ${ }^{97}$ who led a movement of textual verification that coincided with what Gerhard Endress has characterized as an Islamicate form of scholasticism. ${ }^{98}$

91 Sabra, Science and philosophy 21.

92 Marlow, Sirāj al-Dīn Urmavī 282; Endress, Reading Avicenna 304.

93 Endress, Reading Avicenna 408-410.

94 Griffel, Tolerance and exclusion 339-354.

95 For the broader significance of this trend, see Melvin-Koushki, Tahqiq vs. taqlìd 193-249. For its subsequent development, see El-Rouayheb, Opening the gate $263-281$; and Islamic intellectual history.

96 For a brief summary of al-Ghazālī's, al-Juwaynī's, and al-Jurjānī's contributions and roles in the early tahqīq trend, see Cürcânî, Şerhu'-Mevâklf 13-23. Korḳud cited each of these scholars numerous times in Hāafiz al-insān.

97 Ömer Türker's introduction to his Turkish translation of Jurjānīs Sharh al-Mawāqif lists four (al-Rāzī, al-Āmidī, al-İ̄ìi, al-Taftāzānī) of Ḳorḳud's seven as key scholars in the taḥqīq trend. Cürcânî, Şerhu'-Mevâkıf 13-23.

98 Endress, Reading Avicenna in the madrasa 392, 400. 
Korkud's main text engaging with kalām disputation and its role in society, Hāafiz al-insān, followed a long line of Shafi'i legal and Ash'ari theological literature discussing the meaning of true faith and its absence. ${ }^{99}$ In al-Shāfi'i's (d. 204/820) own time, Muslims guilty of internal absence of faith (kufr) were effectively protected by the fact that internal belief was considered a private matter between any individual and his/her God. This de facto protection of religious privacy started to devolve following al-Ghazālī, who argued quite effectively that the phenomenon of zindigs, or secret apostates, necessitated the withdrawal of the right of repentance (tawba) from apostates, as such individuals following secret professions of faith and practicing concealment of inner belief (taqiyya) should not be extended the right to be offered repentance (istitäba). As a result, the definition of apostasy shifted from an individual's public statement breaking away from Islam to the proven existence of an individual's inner conviction consistent with unbelief. ${ }^{100}$

Within Ottoman circles, the most significant legal progression following al-Ghazālì's seminal contribution proved to be the elaboration of acts considered external signs of belief or unbelief. By the early tenth/sixteenth century, the legitimacy of considering such acts as reliable signs was fairly widely accepted, at least among Ottoman scholar-bureaucrats. In addition, it appears that the acts constituting such external signs had multiplied as well. According to Korkud's count, in his own time such acts included: wearing certain clothing reserved for non-Muslim communities under Islamic rule, treating the Quran or other sacred texts with disrespect, bowing down to idols or to the sun, sacrificing animals in someone's name, claiming false prophethood, and practicing sorcery, among others. ${ }^{101}$

Arguments advanced by certain Ottoman religious scholars pushed this legal progression further still, allowing imperial officials to claim shar $i$ justification for punishment of individual apostates as legal justification for statesanctioned violence against entire communities. Korkud's 913/1508 Häfiz alinsān argued for broadening apostate statutes to apply to whole populations and may have played a role in the state's growing politicization of doctrinal

99 This section summarizes a more extensive analysis I previously completed on this same text. See Al-Tikriti, Kaläm in the service 131-149.

100 For further discussion of this earlier evolution of Shafi'i-Ash'ari apostasy literature, see Griffel, Toleration and exclusion 339-354.

101 Ḳorḳud, Hâafiz al-insān 191a-215b. 
affiliation. ${ }^{102}$ Guy Burak has argued that state-affiliated Ottoman ulama by the late ninth/fifteenth century had effectively invented the punishment of "renewal of faith" (tecdìd-i ìmān) as a tactic of "temporary excommunication" in order to discipline doctrinal conformity, punish the expression of beliefs they defined as heretical, and assert their societal power. By utilizing this punishment, expressed solely through fatwa rulings and never articulated as part of Hanafi substantive law, such ulama were able to selectively enforce such conformity without having to attempt to execute every individual offending Muslim under their power. ${ }^{103}$ Although he never advocated for any "renewal of faith" punishment per se, via Häfiz al-insān Ḳorkud contributed to the scholarly dialogue claiming sufficient doctrinal certainty to justify such takfir protocols, which in turn would have justified application of the tecdìd-i imañ punishments.

Hāfizal-insān's benediction affirmed the solitary nature of God and Muhammad's unique status, explaining that Korkud had come across a preponderance of expressions of unbelief among the ignorant, even among those claiming to be seekers of knowledge. To remedy that societal ill, he had decided to clarify the definition of faith and unbelief according to the principles of Islamic jurisprudence and religion, ușül al-figh and ușül al-dìn, informed by the other major branches of learning. ${ }^{104}$ This opening explanation effectively laid out Korkud's disciplinary preferences and agenda, as he intended to demonstrate the doctrinal certainty provided by kalām discourse, assert the legal repercussions springing from that certainty, and thus argue the case for mass application of apostasy protocols against populations displaying external signs of apostasy, in turn justifying violent state reactions to protect religion.

Following the introductory statement, the three remaining sections provided something of a literature review of takfir debates throughout Islamic history up to that point. The first two sections contrasted definitions of faith $(\bar{\imath} m \bar{a} n)^{105}$ and its opposite, kufr. ${ }^{106}$ The third section catalogued and described external acts that point to internal kufr and, thus, merit verdicts of and punishments for apostasy. ${ }^{107}$ By reviewing such takfir debates through the centuries,

\footnotetext{
102 Internal references within the text to Korkud's Da'wat al-nafs and vice-versa confirm this earliest possible date of authorship. Da'watal-nafs al-țaliha is cited three times in Hāfizalinsān 65a, 72a, 196b. Meanwhile, Hāafiz al-insān is cited twice in Da'wat al-nafs 159b, 236a.

103 Burak, Faith, law, and empire 1-23.

104 Korḳud, Hāażzal-insān 1a-b.

105 Ibid. 1a-88b.

106 Ibid. 88b-161b.

107 Ibid. 161b-end.
} 
Korḳud was effectively summarizing a politically relevant subset of kalām discourse to show why state adjudication of heresy was consistent with longstanding religious belief.

In the course of this text, Korkud traced the evolution of faith and unbelief from an inner belief, which only affected one's relationship to God, as it was understood in the third/ninth century, to a legally relevant external expression of religious belief, as it came to be understood in his own day. The way he presented this evolution suggested that the state, acting on behalf of the legists ( fuqah $\vec{a}^{\prime}$ ) in order to protect the status of religion within society, had the right to enforce social conformity and punish those who refuse to conform. In addition, he argued that such external expressions of belief, which are the signs of social conformity addressed here, remain legally material even when compelled. In addition, such expressions (i.e., stating the shahāda, attending Friday prayers) must be displayed to legists regularly, and must be genuine. Possession of ma'rifa (gnosis) cannot provide an excuse for exempting oneself from such ritual practice.

In the second section on unbelief, Korkud started by defining kufr as lack of belief in Muhammad's prophecy, expressed via a number of external acts long recognized as signifying kufr, including scorning the Quran or dressing in clothing meant to signify one's dhimmi status. Citing Ash'ari scholar and Sirāj al-Dīn al-Urmawì's student, al-Ṣafì al-Hindī (d. 715/1315), that denial of faith can be exhibited circumstantially, and al-Taftāzānī's argument that jurists must ensure legal consequences for apostasy when such denial is demonstrated, Korḳud explicitly rejected the older conclusion that an intentional statement of denial is required to confirm kufr. ${ }^{108}$ In addition, he asserted the legitimacy of applying qānün (sultanic law) to certain issues within the scope of shar, such as enforcing the correct interpretation of certain theological matters, since state officials acted as sovereign representatives of the ahl al-haqq (the true community of believers). Although these points seemingly contradicted arguments Korkud made in Da'wat al-nafs al-țaliha concerning ideal ulama primacy and independence vis-à-vis the state, he might have believed that as long as ulama directed such efforts, their status would not be compromised. ${ }^{109}$

In the final section, Korkud affirmed the right of local religious officials to define apostasy locally, thus effectively asserting the right of the Ottoman state through its ulama to define apostasy for its subjects. In addition, he asserted that once the intended meanings of sacred texts are set, such implicit mean-

108 Ibid. 89a-b; on al-Ṣafî al-Hindī, see Marlow, Sirāj al-Dīn Urmavī $3 \circ 9$.

109 Ḳorḳud, Ḥāfiz al-insān 88b-9oa. 
ings can be used as a basis for customary law ('urf) rulings. Theologians must assist practitioners of 'urf to accurately classify such acts and thus protect society from a threat which shar' alone cannot address. ${ }^{110}$ To close the text, Korkud presented acts that merited kufr judgments. The first act was abandoning communal prayer. The second was mishandling the Quran, as well as related texts of the religious sciences and respected sciences, which support the canonical disciplines-but not falsafa and logic texts, or texts that intermix kaläm and falsafa and undermine society's kaläm, and that can therefore be abused with no legal punishment. Other acts included making false claims of prophecy and using sorcery to gain followers. Korkud's final act meriting judgment of kufr was for those donning the qalansuwat al-kuffär (nonbelievers' headgear), who are automatically to be treated as apostates. ${ }^{111}$ This was a clear reference to the Kızılbaş rebel turban, which was spreading throughout Anatolia at the time of his writing. Korkud's generation appears to have been the first to argue that this specific act of public dress constituted apostasy, ${ }^{112}$ thus demonstrating the mutability of external signs of internal kufr over time, as well as the consequences of linking imperial interests with accusations of apostasy. In 913/1508, the same year that Korkud completed a draft of Hāfiz al-insān, thousands of Safavid supporters referred to as "kızıl taçlu" (red crowned) were resettled by Ottoman authorities from Hamid and Teke provinces in Western Anatolia to the recently conquered Modon and Koron provinces in the Peloponnese peninsula. At the time, Korkud was the governing prince of both Hamid and Teke, suggesting a willingness on his part to implement policies justified by his arguments in Häfiz al-insān..$^{113}$

In Hāâz al-insān, Korḳud justified, according to the twin norms of uṣull aldìn (religious dogma) and ușül al-fiqh (sources of Islamic jurisprudence), the right of imperial authorities to apply apostasy verdicts under the prerogatives of 'urf. As such, his contribution can be characterized as one step in a long process reflecting a progressive extension of state hegemony over matters of individual conscience-and toward the modern mass application of takfir as a justification for sectarian violence. This argument coincided in content and conclusions - if not in direct methodology — with those of Kemālpaşazāde and Sarı Gürz Ḥamza Efendi (fl. 920/1514). ${ }^{114}$ Häfiz al-insān also shows ulama

\footnotetext{
110 Ibid. 163b-191a.

111 Ibid. 195a-b.

112 Earlier theologians had mentioned "girding the sash" as an external sign of kufr, thus laying the foundation for clothing-based apostasy rulings.

113 Kayapınar, Anadolu'dan Korona 6-11.

114 Al-Tikriti, Kalām in the service 146-149.
} 
views being granted pride of place by a sympathetic, knowledgeable, and semisovereign prince, as well as the promotion by this same prince of an expansion of shar $\grave{\imath}$ definitions of apostasy to fit imperial interests. On the whole, in this text Korkud's arguments demonstrate the hegemonic extension of imperial control over shar $i$ practice in order to harness the legitimating power of shar $i$ norms to state interests - an extension of state power quite emblematic of the "age of confessionalization," whether in Europe or the Islamic East.

\section{$7 \quad$ Political Repercussions, Societal Observations}

While issues of kalām disputation might not appear to carry strong political repercussions, these debates did not take place in a vacuum, and the prince's arguments appear to have fit a political agenda. Korkud tried to appeal primarily to the Ottoman ulama, who would presumably have agreed with his theological arguments and appreciated his deference to their primacy in matters concerning imperial religious identity. In his view, the interests of religion, defined according to the priorities of those he defined as the ahl al-sunna, trumped the interests of state, and the raison d' etre of the Ottoman state was to support religion. Due to what he perceived as the failure of state and society by the turn of the tenth/sixteenth century, Korkud advocated a return to shari i principles and a move away from a capricious 'urf al-salāțīn (dynastic law). In addition to his positions regarding religious identity, in al-Da'wa Korḳud complained a great deal about state practices that he considered improper according to shar $i$ precepts, including illicit expropriation of wealth via taxation, corruption and abuse by the umară military class, excessive bowing down before the ruler, and extra-shari $\bar{\imath}$ punishments (al-siyassa), particularly in the case of royal fratricide. ${ }^{115}$

Korkud was scathing in his criticism of what he identified as widespread intellectual laziness and corrupt practices in his own era and society. He condemned sectarian madhhab followers who attempted to force agreement from others or reflexively followed the positions of their own school, providing only the justification that such traditions come from their forefathers (taqlid ). As he saw it, individuals must instead search for truth, objectively - another nod to the emerging tahqīq (verification) movement, which Tijana Krstić discusses in this volume in the context of subsequent centuries and from the perspective

115 For a discussion of Ottoman elite attitudes toward the concept of al-siyassa, see Derin Terzioğlu's article in this volume. 
of the sources known as ilm-i hâals, intended for the religious edification of the commoners. ${ }^{116}$ Korkud complained on several levels about the madrasa graduates of his own day, arguing that they were lazy, corrupt, and compromised. He stated that they read only small portions of two classics of Hanafi figh, Sadr al-Sharī'a's hadith collection and Burhān al-Dīn al-Marghīnānīs (d. 593/1197) alHidāya, in order to justify taking illicit funds. Implicitly criticizing the madrasa curriculum first established by the patronage of his grandfather, Mehmed II, Korkud stated that the students of his day, in order to learn Quranic commentary (tafsìr), only read the two glosses by al-Jurjānī and al-Taftāzānī on alZamakhsharì's (d. 538/1144) Kashshäf and what had been commented on them, rather than reading the original work. Finally, in a complaint many university lecturers today might sympathize with, Korkud stated that not only were students reading too narrow a slice of the relevant tafsir literature via these two scholars, they were only reading a few pages. ${ }^{117}$

In order to accomplish his reform agenda, Korkud wished to elevate an independent class of ulama, excepting those who had been transformed into corrupt scholar-bureaucrats, worldly Sufis who were a danger to religion, and judges susceptible to bribes. As he saw it, judges should never rule according to dynastic 'urf code in cases that should be adjudicated according to shar' $\bar{\imath}$ norms, and ulama who frequent palace gates were inherently compromised. His recommendations, if enacted, would have inherently come at the expense of both the military class and certain outsider groups, particularly rural and nomadic Kizllbaş supporters whom Ķorkud and other pillars of state were just beginning to characterize as heretics. ${ }^{118}$ In a sense, his hope was to turn back the clock on the role of the ulama in society, to an idealized past era when he thought they were a privileged group, with an indispensable role to lead society and independent of the political hierarchy. While others might emphasize the importance of the military in jihad, both previously and in his own time, Korkud was convinced that the educational and exhortatory role of the ulama was far more important in jihad than the military role, as only scholars can protect the very essence of religious belief. ${ }^{119}$

As with his views on the mixture of falsafa with kaläm and the role of ulama in society, Korkud railed against several types, or stereotypes, of Sufis. For his discussion on Sufism's role in society, Korḳud supplemented al-Subkī's conclusions with quotes from such prominent Sufi figures as 'Abd al-Rahmmān

\footnotetext{
116 Korkud, Da'wat al-nafs 201a-202a.

117 Korkud, Da'wat al-nafs 221a.

118 Karakaya-Stump, Kizilbash-Alevis in Ottoman Anatolia 256-319.

119 Korḳud, Da'wat al-nafs 114b-115b, 15ob-156b.
} 
al-Sulamī (d. 412/1021), Abū l-Qāsim al-Qushayrī (d. 465/1072), and Shihāb alDīn Abū Ḥafs 'Umar al-Suhrawardī (d. 631/1234). Still, for this section he relied primarily on the Ash'ari Sufi scholar 'Afíf al-Dīn al-Yāfi'îs's (d. 768/1367) mystical

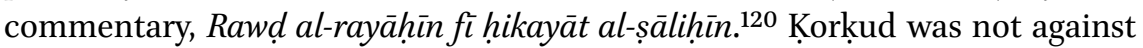
Sufism per se, as he had supported local orders when serving as the governor of Manisa in the 149os. However, he advocated a restrictive approach to the role of institutionalized mysticism in society, going so far as to accuse his own ruling elite of favoring fake Sufis over real ulama. In this vein, he cited al-Subkì's exclusion of "Turks," who had rejected and mocked the fuqahā (legists), from being considered Sufis, which might be taken as an indirect reference to rebellious Safavid followers of his own day. Similarly, he followed al-Yāfici in rejecting magicians, fortune tellers, charlatans, and fake astrologers as Sufis. As Korkud saw it, any individual conjuring up extraordinary acts or miracles in order to persuade people to do what is forbidden must not be followed. ${ }^{121}$

Weighing in on prominent examples from the past, he agreed with certain previous scholars who had judged controversial Sufis. For example, according to Ḳorḳud, al-Hallāj (d. 310/922), Ibn al-Fāriḍ (d. 632/1235), and Ibn 'Arabī were each guilty of various forms of kufr, while 'Ayn al-Quḍāt Hamadānī (d. 525/1131), who was crucified along with other Isma'ilis, joined the Băținiyya and was thus guilty of subverting religion from within. The primary justification for judging any of these figures for committing kufr was their lack of adherence to shar i protocols concerning acceptable belief. Likewise, Korkud spoke out against those guilty in his own day of identifying with what modern scholars sometimes characterize as "latitudinarian Sufism." ${ }^{122}$ For example, as Khiḍr was a saint, not a prophet, he could not be used to excuse shar $\bar{\imath}$ transgressions, as some had claimed. Following al-Ghazālī, Korḳud argued that Sufis claiming exemption from shar $i$ rules and following material pursuits in proximity to the sultan must be condemned for kufr. Likewise, following al-Qurțubī (d. 657/1259), all Bātainiyya Zanādiqa, believing that shar'i rules do not apply to them due to their pure souls and greater intellect, must be condemned for kufr. Following Shihāb al-Dīn Abū Ḥafs 'Umar al-Suhrawardī, one must distinguish between Melami groups, who hide their worship and are honorable, and Qalandari groups, who openly try to destroy tradition. Again following alSuhrawardī, self-proclaimed muftis who claim to be Melami are actually ahl al-ibāha who permit anything, claiming that special truths render them exempt

120 For more on these scholars, see Böwering, al-Sulamī 811-813; Halm, al-Ḳushayrī 526-527; Hartmann, al-Suhrawardī 778-782; and Geoffrey, al-Yāfi'î 236 .

121 Korkud, Da'wat al-nafs 223a-248b.

122 Fleischer, From Ḳorḳud to Mustafa Āli 72. 
from shar'i precepts. Such individuals are not Sufis and are a source of all types of zandaqa, ilhād (heresy), and $i b \bar{a} d$ (estrangement). Likewise, those who believe in the transmigration of souls must be condemned, as with the two most famous examples of "ecstatic Sufism," when al-Ḥallāj stated "Anā al-ḥaqq" and Bāyezīd al-Bisțāmī (d. ca. 26o/874) stated "Ṣubḥānī" Citing alQushayrī and al-Sulamī, Korḳud pointed out that the same Bāyezīd al-Bisțāmī had also cautioned against following one promising miracles (karāmāt) until one knows where he stands in relation to the shar $\imath$ limits. Here Korḳud may have been indirectly referring to his own contemporary Shah Ismāill, who was widely reported to be capable of bringing about miracles. To provide a positive example, he stated that all three of these Sufi commentators agreed that Junayd (d. 297/910), the epitome of "sober Sufism," was both a genuine Sufi and a sound Shafi'i. ${ }^{123}$

In Häfiz al-insān, Korḳud characterized contemporary opponents to his use of scriptural revelation as the basis for secular legal pronouncements as the "Murji'a," who rejected the earthly legal intent of scripture and called for a sufficiently narrow reading of Quranic verses and hadith accounts as to obviate material legal conclusions. ${ }^{124}$ Another set of opponents were the "Bāținiyya," who claimed that the secret meanings within sacred texts are known only to a guide with special knowledge. He considered those he characterized as the Bătininya more dangerous than the Murji'a, and stated that anyone holding such views is ipso facto a murtadd (apostate). ${ }^{125}$

A Mixed Legacy

Korkud's contributions left a mixed legacy within the early articulation of an imperial religious identity that one can refer to as "Ottoman Sunnism." As such, he engaged with kaläm debates, critiqued the field, and commented on it and related disciplines' role in society, particularly in the education of Ottoman youth. While Da'wat al-nafs al-țăliha and Häfiz al-insān are not, strictly speaking, kalām works, through these texts Şehzāde Korḳud engaged directly with kaläm, and commented on the role kalām and related disciplines were already coming to play in the development of Ottoman Sunni identity.

\footnotetext{
123 Korḳud, Da'wat al-nafs 223a-248b.

124 Korḳud, Hāâz al-insān 13ob-158b. For more on the Murji'a doctrine, see Madelung, Murdji'a 6o5-6o7.

125 Korḳud, Häfiz al-insān 157b-161b.
} 
Ḳorḳud's support for Fakhr al-Dīn al-Rāzī's medial position between extreme supporters of 'aql and naql alone remained popular for years to come, even though Ottoman kalām eventually inched ever closer to a primarily 'aql dominant perspective. Likewise, state officials agreed broadly with justifications put forth in Hâfiz al-insān for defining, judging, and punishing apostasy, with immediate political effect. His support for state involvement in crafting religious identity also carried the day, as court-affiliated ulama rolled out heresy accusations against the emergent Kızlbaş challenge-none of which is surprising in the broader context of a nascent "age of confessionalization."

However, Korkud's promotion of a specific "third madhhab," opposition to mixing falsafa with kaläm at the latter's expense, condemnation of Ibn 'Arabī, and preference for Shafi'i fiqh and Ash'ari kaläm, ultimately met with tepid reactions within the Ottoman elite. Within a generation of Korkud's death, some of his favored scholars faded from view while his proposed "third mad$h h a b$ " was forgotten as an intellectual construct. Likewise, Ibn 'Arabī was practically enshrined as an imperial saint, the state preference for Hanafi figh grew ever more institutionalized, and madrasa graduates progressively articulated a recognizably Ottoman brand of Maturidi kalām heavily infused with falsafa methodology and views. Just as his ruling candidacy was marginalized and largely forgotten, several of Şehzāde Korḳud's views on religious practice came to represent an Ottoman path not taken-as well as a proof of the spectrum of views inherent within Ottoman Sunnism.

\section{Acknowledgments}

I wish to thank the anonymous reviewer, M. Sait Özervarl, Tijana Krstić, Derin Terzioğlu, and Urs Gösken for their comments and criticisms offered in the course of developing this contribution.

\section{Bibliography}

\section{Primary Sources}

Topkapı Sarayı Müzesi Arşivi (Istanbul, Turkey): Dıoo17; E6366/1.

[Al-Abharī and al-Maybudī], "Commentary upon guidance through wisdom (from Sharh hidayyat al- hikmat)," trans. N. Heer, with an introduction by S.H. Nasr, in S.H. Nasr and M. Aminrazavi (eds.), An anthology of philosophy in Persia: From the school of Illumination to philosophical mysticism, iv, London 2012, 269-286.

Cürcânî, Şerhu 'l-Mevâkıf, trans. Ö. Türker, 3 vols., Istanbul 2015. 
Hoca Sa'dü'd-dīn, Tācü't-tevārīh, 2 vols., Istanbul 1863.

İbn Kemâl, Tevârīh-i Âl-i Oșmân (transkripsiyon), viii, ed. A. Uğur, Ankara 1997.

Kātib Çelebi, Kashf al-zunūn 'an asāmì l-kutub wa-l-funūn, 7 vols., ed. G. Flügel, London and Leipzig $1835^{-1858 .}$

Kemālpaşazāde, al-Ikhtilāf bayna al-Ash'ariyya wa-l-Māturīdiyya, Süleymaniye Kütüphanesi, Ms Laleli 3711, 116a-118a.

Korḳud, Şehzāde, Da'wat al-nafs al-țāliḥa ilā al-a'māl al-ṣāliḥa, Ms Gökbilgin (private); Süleymaniye Kütüphanesi, Ms Aya Sofya 1763 .

Korḳud, Şehzāde, Hāfiz al-insān 'an lāfiz al-ìmān wa-Allāh al-hādī ilā șirāt al-jinān, Süleymaniye Kütüphanesi, Ms Aya Sofya 2289.

Korḳud, Şehzāde, Hall ishkāl al-afkār fi ḥill amwāl al-kuffār, Süleymaniye Kütüphanesi, Ms Aya Sofya 1142.

Mecdî, M., Hadâiku'ş-şakâik, ed. A. Özcan, Istanbul 1989.

Müstaḳimzāde, S.S., Tuhfe-i haț̣aț̣in, ed. İ.M. Kemāl [İnal], Istanbul 1928.

Suhrawardī, The shape of light: Hayākil al-nūr, trans. T. Bayrak, Louisville 1998.

Taşköprüzade, al-Shaqā’iq al-nu'māniyya fi 'ulamā' al-dawlat al-'Uthmāniyya, ed. A.S. Furat, Istanbul 1985 .

\section{Secondary Sources}

Ahmed, S. and N. Filipović, The sultan's syllabus: A curriculum for the Ottoman imperial medreses prescribed in a fermān of Qānūnī I Süleymān, dated 973 (1565), in SI 98/99 (2004), 183-218.

Atçl, A., Greco-Islamic philosophy and Islamic jurisprudence in the Ottoman Empire (1300-16oo): Aristotle's theory of science in works on uṣūl al-fiqh, in Jos 41 (2013), $33-54$.

Atçll, A., Scholars and sultans in the early modern Ottoman Empire, Cambridge 2017.

Badeen, E., Sunnitische Theologie in osmanischer Zeit, Würzburg 2008.

Bebek, A., Hayâlî, in TDVIA, xvii, 3-5.

Berger, L., Interpretations of Ash'arism and Māturīdism in Mamluk and Ottoman times, in S. Schmidtke (ed.), The Oxford handbook of Islamic theology, Oxford 2016, 693701.

Böwering, G., al-Sulamī, in $E I^{2}$, ix, 811-812.

Burak, G., Faith, law, and empire in the Ottoman "age of confessionalization" (fifteenthseventeenth centuries): The case for "renewal of faith," in Mediterranean historical review 28 (2013), 1-23.

Burak, G., The second formation of Islamic law: The post-Mongol context of the Ottoman adoption of a school of law, in Comparative studies in law and society 55 (2013), 579-6o2.

Chelkowski, P., Niz̄āmī Gandjawī, in $E I^{2}$, viii, 76-81.

Corbin, H., History of Islamic philosophy, trans. L. Sherrard, London 2001. 
Dalkıran, S., İbn-i Kemal ve düşünce tarihimiz, Istanbul 1997.

Eichner, H., Handbooks in the tradition of later eastern Ash'arism, in S. Schmidtke (ed.), The Oxford handbook of Islamic theology, Oxford 2016, 494-514.

Emecen, F., Korkut, Şehzade, in TDVIA, xxvi, 205-207.

Endress, G., Reading Avicenna in the madrasa: Intellectual genealogies and chains of transmission of philosophy and the sciences in the Islamic East, in J.E. Montgomery (ed.), Arabic theology, Arabic philosophy: From the many to the one, Leuven 2006, 371-422.

Erünsal, İ.E., Molla Lütfi zındıklık ithamıyla mı öldürüldü? in Marmara Üniversitesi hukuk fakültesi hukuk araştırmaları dergisi: Mehmet Âkif Aydın'a armağan 21 (2015), 37-54.

Fleischer, C., From Şeyhzade [sic] Korkud to Mustafa Āli: Cultural origins of the Ottoman nasihatname, in Proceedings of the IIIrd congress on the social and economic history of Turkey, Istanbul 1990, 67-77.

Frank, R., al-Ghazālī's use of Avicenna's philosophy, in REI 55-57 (1987-1989), 271285 .

Furat, A.H., Osmanlı hânedanında Şâfiî bir fakîh: Şehzade Korkud (ganimet ahkâmıyla alakalı "Kitabu halli işkâli'l-efkâr fî hilli emvâli'l-küffâr" isimli eseri bağlamında), in Ekev akademi dergisi 14 (2010), 193-212.

Gardet, L. 'Ilm al-kalām, in $E I^{2}$, iii, 1141-1150.

Geoffroy, E., Le Soufisme en Egypte et en Syrie sous les derniers Mamelouks et les premier Ottomans: Orientations spirituelles et enjeux culturels, Damascus 1995.

Geoffrey, E., al-Yāfi'ì, in $E I^{2}, x i, 236$.

Gökbilgin, M.T., Korkud, in $E I^{2}$, v, 269.

Gökbilgin, M.T., Korkut, in $I A$, vi, 855-86o.

Görgün, T., el-Îcî, Adudüddin, in TDVIA, xxi, 410-414.

Griffel, F., Toleration and exclusion: al-Shāfiī and al-Ghazālī on the treatment of apostates, in BSOAS 54 (2001), 339-354.

Gümüş, S., Cürcânî, Seyyid Şerîf, in TDVIA, viii, 134-136.

Gümüş, S., Seyyid Şerif Cürcânîve Arap dilindeki yeri, Istanbul 1984.

Halm, H., al-Kushayrī, in $E I^{2}$, v, 526-527.

Hartmann, A., al-Suhrawardī, in $E I^{2}$, ix, $77^{8}-782$.

Heffening, W., al-Muzanī, in $E I^{2}$, vii, 822.

Hoover, J., Hanbali theology, in S. Schmidtke (ed.), The Oxford handbook of Islamic theology, Oxford 2016, 625-648.

Hüsāme'd-dīn, H., Amasya tārīhi, 4 vols., Istanbul 19o9-1912.

Ingalls, M., Recasting Qushayrī's Risāla in fifteenth-century Egypt, in Journal of Sufi studies 2 (2013), 93-120.

Kalaycı, M., Mâtürîdî-Hanefî aidiyetin Osmanlı'daki izdüşümleri, in Cumhuriyet ilahiyat dergisi 20 (2016), 9-72. 
Kalaycı, M., Eşarilik ve Maturidiliği uzlaştırma girişimleri: Tacüddin es-Sübki ve Nuniyye kasidesi, in Dini araştırmalar 15 (2012), 112-131.

Kappert, P., Die Osmanischen Prinzen und ihre Residenz Amasya im 15 und 16 jahrhundert, Leiden 1976.

Karakaya-Stump, A., The Kizilbash-Alevis in Ottoman Anatolia: Sufism, politics, and community, Edinburgh 2019.

Kayapınar, L. Anadolu'dan Koron ve Modon'a Kızıl Taçluların iskânı, in Alevilik-Bektaşilik araştırmaları dergisi 14 (2016), 3-17.

Krstić, T., Illuminated by the light of Islam and the glory of the Ottoman sultanate: Selfnarratives of conversion to Islam in the age of confessionalization, in Comparative studies in society and history 51 (2009), 35-63.

Madelung, W., al-Isfarāyīnī, in $E I^{2}$, iv, 107-108.

Madelung, W., Murdji'a, in $E I^{2}$, vii, $605^{-607 .}$

Madelung, W., al-Taftāzānī, in $E I^{2}, \mathrm{x}, 88-89$.

Markiewicz, C., The crisis of rule in late medieval Islam: A study of Idrīs Bidlīsī (861926/1457-1520) and kingship at the turn of the sixteenth century, PhD diss., University of Chicago 2015 .

Marlow, L., A thirteenth-century scholar in the eastern Mediterranean: Sirāj al-Dīn Urmavī, jurist, logician, diplomat, in al-Masāq 22 (2010), 279-313.

Mekki Efendi, Ş. and A. Neyli Efendi, Yavuz Sultan Selim'in emriyle hazırlanan Ibn alArabi müdafaası, Istanbul 2004.

Melvin-Koushki, M., Tahqīq vs. taqlìd in the renaissances of western early modernity, in Philological encounters 3 (2018), 193-249.

Menzel, T., Mu'ayyad-zāde, in $E I^{2}$, vii, 272.

Nasr, S.H., Islamic philosophy from its origin to the present, Albany 2006.

Nasr, S.H. and M. Aminrazavi, An anthology of philosophy in Persia, 5 vols., London 2012.

Ocak, A.Y., Osmanlı toplumunda zındıklarve mülhidler (15-17. yüzyıllar), Istanbul 1998.

Osborne, J.R., Letters of light: Arabic script in calligraphy, print, and digital design, Cambridge, MA 2017.

Özel A. and C. Kallek, Zekeriyyâ el-Ensârî, in TDVIA, xliv, 212-215.

Özen, Ş, Teftâzânî, in TDVIA, xl, 299-308.

Özervarl, M.S., Theology in the Ottoman lands, in S. Schmidtke (ed.), The Oxford handbook of Islamic theology, Oxford 2016, $567-584$.

Peters, R., What does it mean to be an official madhhab: Hanafism and the Ottoman Empire, in P. Bearman, R. Peters and F. Vogel (eds.), The Islamic school of law: Evolution, devolution, and progress, Cambridge, MA 2005, 147-158.

Pfeiffer, J., Teaching the learned: Jalāl al-Dīn al-Dawānī’s ijāaza to Mu'ayyadzāda 'Abd alRaḥmān Efendi and the circulation of knowledge between Fārs and the Ottoman Empire at the turn of the sixteenth century, in M.A. Pomerantz and A.A. Shahin 
(eds.), The heritage of Arabo-Islamic learning: Studies presented to Wadad Kadi, Leiden 2016, 284-331.

Pourjavady, R., Philosophy in early Safavid Iran, Leiden 2011.

Pourjavady, R. and S. Schmidtke, Twelver Shi'ì theology, in S. Schmidtke (ed.), The Oxford handbook of Islamic theology, Oxford 2016, 456-469.

Rizvi, S.H., Selfhood and subjectivity in Safavid philosophy: Some notes on Mīr Giiyātuddīn Manșūr Daštakī, in Ishraq 5 (2014), 97-115.

El-Rouayheb, K., Islamic intellectual history in the seventeenth century: Scholarly currents in the Ottoman Empire and the Maghreb, Cambridge 2015.

El-Rouayheb, K., Opening the gate of verification: The forgotten Arab-Islamic florescence of the 17th century, in IJMES 38 (2006), 263-281.

Rudolph, U., R. Hansberger and P. Adamson (eds.), Philosophy in the Islamic world, Volume I: 8th-1oth Centuries, Leiden 2016.

Sabra, A.I., Science and philosophy in medieval Islamic theology: The evidence of the fourteenth century, in Zeitschrift für Geschichte der Arabisch-Islamischen Wissenschaften 9 (1994), 1-42.

Sariyannis, M., The princely virtues as presented in Ottoman moral and political literature, in Turcica 43 (2011), 121-144.

Smith, W.C., The concept of Sharīa among some mutakallimūn, in Arabic and Islamic studies in honor of Hamilton A.R. Gibb, Leiden 1965, 581-6o2.

Sohrweide, H., Dichter und Gelehrte aus dem Osten im Osmanischen Reichs (1453160o): Ein Beitrag zur türkisch-persischen Kulturgeschichte, in Der Islam 46 (1970), 275-276.

Spannaus, N., Theology in Central Asia, in S. Schmidtke (ed.), The Oxford handbook of Islamic theology, Oxford 2016, 587-6o1.

Subtelny, M.E. and A.B. Khalidov, The curriculum of Islamic higher learning in Timurid Iran in the light of the Sunni revival under Shāh-Rukh, in JAOS 115 (1995), 210236.

Ṭāhir, B.M., Ośmanlı mü'ellifleri, 3 vols., Istanbul, 1914-1924.

Thiele, J., Recent developments in the field of kaläm, in SI 113 (2018), 223-243.

Al-Tikriti, N., Şehzade Korḳud (ca. 1468-1513) and the articulation of early 16th-century Ottoman religious identity, $\mathrm{PhD}$ diss., University of Chicago 2004.

Al-Tikriti, N., The hajj as justifiable self-exile: Şehzade Korḳud's Wasīlat al-ạ̣bāb (915916/1509-1510), in al-Masāq 17 (2005), 125-146.

Al-Tikriti, N., Kalām in the service of state: Apostasy and the defining of Ottoman Islamic identity, in H. Karateke and M. Reinkowski (eds.), Legitimizing the order: Ottoman rhetoric of state power, Leiden 2005, 131-149.

Tosun, N., Mâtürîdiyye ve tasavvuf ilişkisi, in Tasavvuf: İlmî ve akademik araştırma dergisi 38 (2016), 47-54.

Tritton, A.S., al-Djūrdjānī, in $E I^{2}$, ii, 6o2-6o3. 
Uzunçarşıll, İ.H., II'inci Bayezid'in oğullarından Sultan Korkut, in Belleten 30 (1966), 539-6o1.

Uzunçarşılı, İ.H., Fatih Sultan Mehmed'in ölümü, in Belleten 39 (1975), 474-475.

Uzunçarşıll, İ.H., Osmanlı devletinin ilmiye teşkilâtı, Ankara 1965.

van Ess, J., al-Īdjī, in $E I^{2}$, vii, 1022.

Versteegh, C.H.M., al-Zamakhsharī, in $E I^{2}$, xi, 432-434.

Wensinck, A.J., al-Nasafī, in $E I^{2}$, vii, 968-969.

Würtz, T., Islamische Theologie im 14. Jahrhundert: Auferstehungslehre, Handlungstheorie und Schöpsfungsvorstellungen im Werk von Sa'd ad-Dīn at-Taftāzānī, Berlin 2016.

Yavuz, S.S., Isferāyīnī, Ebū Ishāk, in TDVIA, xxii, 515-516.

Yavuz, Y.Ş., Nesefï, Ebü'l-Muīn, in TDVIA, xxxii, 568-570.

Yazıcıoğlu, M.S., Le kalām et son rôle dans la société turco-ottomane aux XVe et XVIe siècles, Ankara 1990.

Yazıcıŏ̆lu, M.S., Hızır Bey, in TDVIA, xvii, 413-415.

Yıldırım, R., Sunni orthodox vs. Shi'ite heterodox?: A reappraisal of Islamic piety in medieval Anatolia, in A.C.S. Peacock, B. de Nicola and S.N. Yıldız (eds.), Islam and Christianity in medieval Anatolia, London 2015.

Yllmaz, H., Caliphate redefined: The mystical turn in Ottoman political thought, Princeton 2018. 